\title{
Progesterone synthesis in the nervous system: implications for myelination and myelin repair
}

\author{
Michael Schumacher ${ }^{1}{ }^{*}$, Rashad Hussain ${ }^{1}$, Nathalie Gago ${ }^{1+}$, Jean-Paul Oudinet ${ }^{1}$, Claudia Mattern $^{2}$ and \\ Abdel M. Ghoumari ${ }^{1}$
}

${ }^{1}$ UMR 788, INSERM and University Paris-Sud, Kremlin-Bicêtre, France

${ }^{2} M$ et $P$ Pharma AG, Emmetten, Switzerland

\section{Edited by:}

Kazuyoshi Tsutsui, Waseda University, Japan

Reviewed by:

Delia Belelli, Ninewells Hospital and Medical School, UK

Nathalie A. Compagnone, Innovative Concept in Drug Development, France

\section{*Correspondence:}

Michael Schumacher, INSERM UMR 788, 80, rue du Général Leclerc, 94276 Kremlin-Bicêtre, France. e-mail: michael.schumacher@ inserm.fr

\section{${ }^{\dagger}$ Present address:}

Nathalie Gago, Facultad de Medicina, Universidad Central de Venezuela,

Caracas, Venezuela
Progesterone is well known as a female reproductive hormone and in particular for its role in uterine receptivity, implantation, and the maintenance of pregnancy. However, neuroendocrine research over the past decades has established that progesterone has multiple functions beyond reproduction. Within the nervous system, its neuromodulatory and neuroprotective effects are much studied. Although progesterone has been shown to also promote myelin repair, its influence and that of other steroids on myelination and remyelination is relatively neglected. Reasons for this are that hormonal influences are still not considered as a central problem by most myelin biologists, and that neuroendocrinologists are not sufficiently concerned with the importance of myelin in neuron functions and viability. The effects of progesterone in the nervous system involve a variety of signaling mechanisms. The identification of the classical intracellular progesterone receptors as therapeutic targets for myelin repair suggests new health benefits for synthetic progestins, specifically designed for contraceptive use and hormone replacement therapies. There are also major advantages to use natural progesterone in neuroprotective and myelin repair strategies, because progesterone is converted to biologically active metabolites in nervous tissues and interacts with multiple target proteins. The delivery of progesterone however represents a challenge because of its first-pass metabolism in digestive tract and liver. Recently, the intranasal route of progesterone administration has received attention for easy and efficient targeting of the brain. Progesterone in the brain is derived from the steroidogenic endocrine glands or from local synthesis by neural cells. Stimulating the formation of endogenous progesterone is currently explored as an alternative strategy for neuroprotection, axonal regeneration, and myelin repair.

Keywords: progesterone, allopregnanolone, progestins, neurosteroids, myelin, multiple sclerosis, oligodendrocytes, Schwann cells

\section{INTRODUCTION}

Over the past two decades, the pleiotropic effects which steroids exert throughout the nervous system have become an active area of investigation in neuroendocrine science. Since the pioneering studies of the biosynthesis, mechanisms of action, and effects of steroids in the brain in the late 1980s and early 1990s, extensive investigations have improved our knowledge in this field.

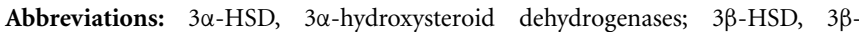
hydroxysteroid dehydrogenase; $5 \alpha$-DHP, $5 \alpha$-dihydroprogesterone; BrdU, bromodeoxyuridine; CMT, Charcot-Marie-Tooth diseases; CNS, central nervous system; DRG, dorsal root ganglia; EAE, experimental autoimmune encephalomyelitis; ER, estrogen receptor; $\mathrm{GABA}_{\mathrm{A}}$ receptors, $\gamma$-aminobutyric acid type A receptors; HRT, hormone replacement therapy; IPSCs, inhibitory postsynaptic currents; LPC, lysolecithin or lysophosphatidylcholine; MBP, myelin basic protein; MCAO, middle cerebral artery occlusion; MPA, medroxyprogesterone acetate (Provera); OPC, oligodendrocyte progenitor cells; OPP, oligodendrocyte pre-progenitors; P0, protein zero; PLP, proteolipid protein; PMP22, peripheral myelin protein-22; PNS, peripheral nervous system; PR, progesterone receptor; PRE/GRE, progesterone and glucocorticoid response element; TBI, traumatic brain injury; TSPO, translocase $18 \mathrm{kDa}$.
Remarkably, experimental studies have recently translated into clinical trials (Schumacher et al., 2008; Stein and Wright, 2010; El-Etr et al., 2011).

With the first observations that steroids regulate the synthesis of neurotransmitters and the activity of neurotransmitter receptors, it became evident that their actions in the brain extend well beyond reproduction and adaptation to stress (Luine et al., 1980; Majewska et al., 1986). Moreover, estradiol was shown to have marked influences on synaptic and dendritic spine plasticity (Gould et al., 1990; McEwen, 2001). Neuroprotective effects of both progestagens and estrogens were then demonstrated in different experimental models of nervous system injury, ranging from middle cerebral artery occlusion (MCAO), excitotoxic neuron death, and traumatic brain injury (TBI) to spinal cord lesions (Garcia-Segura et al., 2001; Stein, 2001; Wise, 2002; De Nicola et al., 2009).

Soon after the discovery that some steroids, and in particular pregnenolone and progesterone, can be synthesized de novo from cholesterol within the nervous system, these so-called "neurosteroids" were proposed to play a role in myelination (Baulieu, 
1997). This hypothesis was based on the observations that: (1) progesterone is produced by cultures of glial cells incubated in the presence of steroid precursors; (2) adding progesterone to mixed glial cell cultures prepared from neonatal rat brains increases the proportion of oligodendrocytes, the myelinating cells of the central nervous system (CNS); (3) oligodendrocytes may express progesterone receptors $(\mathrm{PR})$, although this particular point remains to be clarified as no double labeling with cell-specific markers was performed (Jung-Testas et al., 1989, 1991). A few years later, it was demonstrated that progesterone synthesis by Schwann cells, the myelinating cells of the peripheral nervous system (PNS), plays an important role in the myelination of peripheral nerves (Koenig et al., 1995).

The lipid-rich and insulating myelin sheaths, which surround axons in the vertebrate nervous system, are required for the rapid saltatory conduction of nerve impulses (Baumann and Pham-Dinh, 2001; Hartline and Colman, 2007). The importance of myelin is documented by neurological disorders, ranging from inherited dysmyelinating diseases characterized by defective myelin formation, including leukodystrophies and peripheral neuropathies such as Charcot-Marie-Tooth diseases (CMT), to acquired demyelinating diseases involving the destruction of existing myelin sheaths, such as multiple sclerosis. Importantly, recent research has revealed that myelin, in addition to its role in rapid nerve conduction, also provides trophic support to axons, essential for their functional integrity, and the survival of neurons (Yin et al., 2006; Nave and Trapp, 2008). For this reason, axonal degeneration and neuron death are common hallmarks of myelin disorders, and it is urgent to replace lost myelin after nervous tissue lesions.

This review will focus on the role of progestagens in myelin formation. Initially, the terms "progestagens" or "progestogens" referred to natural or synthetic steroids which prepare the uterus for pregnancy. In the light of the multiple functions of progesterone, we propose to extend this functional definition to include the neuroactive metabolites of progesterone. The term "progestin," which is not used in a consistent manner in the scientific literature, will refer here to synthetic progestagens, developed to target the classical intracellular PR (Schumacher et al., 2007). As a historical reminder, the term "progestin" initially referred to the ovarian hormone which supports and assists pregnancy, but after its isolation and identification in 1934, the name progesterone was proposed for common use in the scientific literature (Stanczyk and Henzl, 2001). Unfortunately, the term progesterone, which should only designate the "natural" or "bioidentical" hormone, continues to be used in the medical literature as a generic one for the different types of natural and synthetic progestagens, thus creating confusion.

\section{MYELINATION AND REMYELINATION IN THE CENTRAL AND PERIPHERAL NERVOUS SYSTEMS}

In the CNS, oligodendrocytes can extend up to 40 processes, each enveloping an axon stretch with a compact myelin sheath, and adjacent myelin segments of a same axon may belong to different oligodendrocytes (Baumann and Pham-Dinh, 2001). As a consequence, the death of a single oligodendrocyte results in myelin loss and in the interruption of electrical impulses for many axons. Whereas neuronal regeneration is limited within the CNS, lost myelin can be replaced after injury or during demyelinating diseases as part of a natural healing process. This process, named "remyelination" or "myelin repair," requires the generation of new oligodendrocytes from oligodendrocyte progenitor cells (OPC; Chang et al., 2002; Franklin and FFrench-Constant, 2008). In the adult brain and spinal cord, OPC are ubiquitous and represent a large percentage of the total cell population, as much as $9 \%$ of cells in white matter and 3\% in gray matter (Nishiyama, 2001; Dawson et al., 2003). In response to a demyelinating lesion, adult OPC start proliferating and are recruited to the demyelinated axons, where they differentiate into mature, myelin-forming oligodendrocytes. The different stages of maturation toward myelinating oligodendrocytes can be identified by cell type-specific markers (Figure 1A). Our laboratory has isolated from postnatal day 2 rat brains a very early stage of progenitors, named early PSA$\mathrm{NCAM}^{+}$pre-progenitors (early OPP), which still do not respond to platelet-derived growth factor-AA (PDGF-AA), a key growth factor of OPC, but instead proliferate in response to epidermal growth factor, a growth factor for early neural progenitors (Gago et al., 2003). As discussed later in more detail, early OPP synthesize progesterone and its metabolite allopregnanolone, involved in a complex autocrine loop controlling their proliferation (Gago et al., 2004).

It is important to draw here attention to differences between developmental myelination and myelin repair in the adult CNS. Although both processes share many similarities, and the study of developmental myelination contributes to our understanding of myelin regeneration, there are also divergences concerning the role of transcription and growth factors. Adult OPC are indeed distinct from the perinatal ones (Fancy et al., 2011; Huang and Franklin, 2011). Importantly, myelin also regenerates in patients with multiple sclerosis during the early relapsing/remitting stages, but as the disease progresses, the remyelination of axons becomes insufficient and repair fails, possibly because of deficient adult OPC recruitment and differentiation (Kuhlmann et al., 2008). Stimulating these processes has recently been recognized as a major therapeutic challenge for demyelinating diseases (Franklin and FFrench-Constant, 2008).

Reciprocal communication between oligodendrocytes, neurons, and astrocytes plays a key role in the formation of new myelin sheaths (Talbott et al., 2005; Ishibashi et al., 2006; Simons and Trajkovic, 2006). Thus, steroids may stimulate the myelination and remyelination of axons directly by acting on oligodendrocytes, or indirectly via their effects on neurons or astrocytes. However, it is likely that they act in a concerted manner on multiple neural cell types.

In the PNS, myelin sheaths are formed by Schwann cells, the only glial cell type in peripheral nerves. Peripheral and central myelin also differs in protein content. The two major protein constituents of CNS myelin are proteolipid protein (PLP) and myelin basic protein (MBP; Quarles et al., 2006). PLP plays an important role in myelin membrane stability and sustains axonal functions (Yin et al., 2006). MBP has many splice variants, which are developmentally regulated. In adult myelin, the role of the predominant $18.5 \mathrm{kDa}$ isoform is to maintain the structural integrity and compaction of the myelin sheaths (Harauz et al., 2009). In peripheral myelin, the transmembrane protein zero (P0) replaces PLP as the major protein, although myelin-forming Schwann cells 


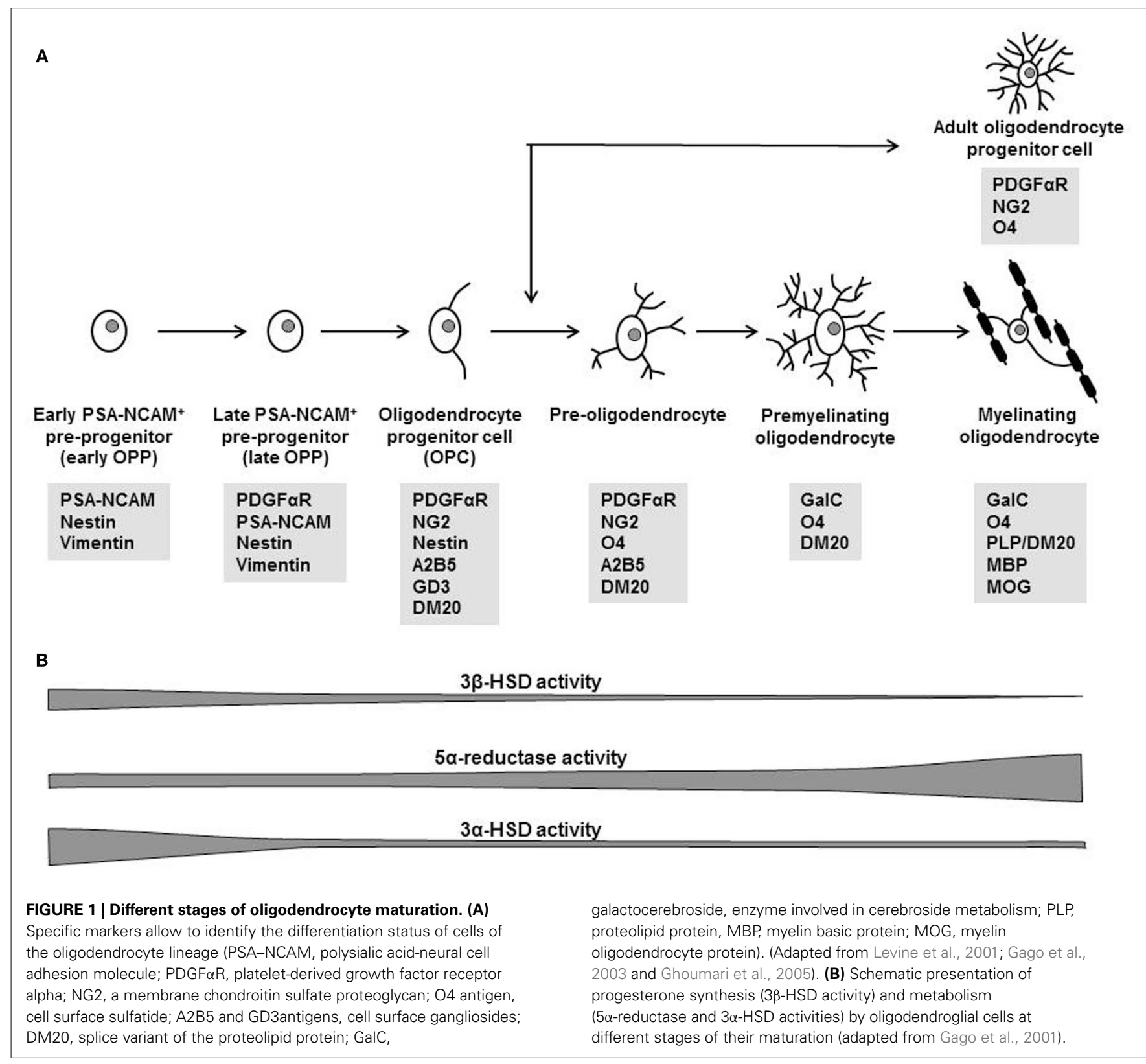

also express low levels of PLP (Quarles et al., 2006). Besides its role in myelin structure, P0 is involved in neuron-glial interactions (Eichberg, 2002). Mutations in the PO gene are at the origin of neuropathies collectively known as Charcot-Marie-Tooth disease type 1B (CMT1B; Shy, 2006). In addition to the major P0 glycoprotein, compact PNS myelin contains peripheral myelin protein-22 (PMP22), which accounts for less than 5\% of the total protein. The functions of PMP22 are not completely understood, but the protein may be involved in myelin assembly and maintenance (Quarles et al., 2006). Duplication of one PMP22 allele causes CMT1A, the most common form of inherited neuropathies and characterized by the demyelination and loss of axons. On the contrary, deletion of one PMP22 allele causes a milder neuropathy with liability to pressure palsies (Suter and Scherer, 2003). Indeed, different myelin proteins need to be expressed at precise levels and ratios to ensure not only the correct formation of myelin sheaths, but also their stability and maintenance. Thus, already a small change in the ratio of different myelin proteins can lead to demyelinating peripheral neuropathies (Giambonini-Brugnoli et al., 2005). The same is true for the CNS, were disturbed myelin gene dosage results in severe myelin disorders (Karim et al., 2007). For this reason, myelin genes are qualified as dosage-sensitive.

Whereas PNS and CNS myelin proteins are very different, myelin lipids are qualitatively very similar and only differ quantitatively (Quarles et al., 2006). The steroid cholesterol is a major lipid constituent of the myelin membrane, representing about $25 \%$ of the total myelin lipids, and this explains why $25 \%$ of the total amount of cholesterol present in the human body is localized to the brain (Björkhem and Meaney, 2004; Chrast et al., 2011). All nervous system cholesterol is derived from local synthesis by 
glial cells, as the blood-brain-barrier and the blood-nerve barrier are not permeable to the steroid (Jurevics and Morell, 1995; Morell and Jurevics, 1996; Jurevics et al., 1998). Thus, cholesterol may be considered as a typical neurosteroid. In the CNS, the large amounts of cholesterol required for the synthesis of myelin are produced by the oligodendrocytes themselves. This has been demonstrated by selectively inactivating in oligodendrocytes the expression of the squalene synthase, a key enzyme involved in cholesterol biosynthesis (Saher et al., 2005). Similarly, peripheral nerves are hypomyelinated if cholesterol biosynthesis is lacking in Schwann cells (Saher et al., 2009).

There are other fundamental differences between Schwann cell and oligodendrocyte myelination. Whereas a single oligodendrocyte myelinates portions of multiple adjacent axons, Schwann cells only myelinate one segment of a single axon. Moreover, in contrast to oligodendrocytes, Schwann cells are characterized by a remarkable plasticity. Whereas remyelination in the CNS requires the recruitment of progenitor cells and their differentiation into new oligodendrocytes, Schwann cells have the capacity to dedifferentiate and to assume a phenotype similar to immature cells in response to injury. This process also represents an essential step in axonal regeneration, as Schwann cells are a major local source of growth factors and neurosteroids (Mirsky et al., 2008). Peripheral axons, in contrast to the limited capacity of regeneration of central axons, indeed regrow spontaneously after injury thanks to a permissive environment and the intrinsic regenerative capacity of neurons (Chen et al., 2007). Once again in contact with the regenerating axons, Schwann cells differentiate and form new myelin sheaths (Fawcett and Keynes, 1990; Chen et al., 2007). Remyelination is regulated by axonal signals, which differ between Schwann cells and oligodendrocytes (Chan et al., 2004; Brinkmann et al., 2008). Schwann cells only express a myelinating phenotype when they are in contact with large axons producing threshold levels of neuregulin-1 type III (Michailov et al., 2004).

In both CNS and PNS, myelin formation is also under the influence of progesterone, either derived from the steroidogenic endocrine glands or from local synthesis. A role for progesterone in myelin formation was first demonstrated in the PNS, and this original observation was subsequently extended to the CNS. However, before discussing the role of progesterone in myelin formation, we shall examine the different sources of progesterone in the nervous system.

\section{SOURCES OF PROGESTERONE IN THE CENTRAL NERVOUS SYSTEM}

Progesterone is produced by the corpus luteum of the ovary during the proestrous stage of the rodent estrous cycle and during the luteal phase of the menstrual cycle in women. In pregnancy, the ovary remains the main source of progesterone in rodents, whereas in humans, progesterone is mainly produced by the placenta (Arensburg et al., 1999; Tuckey, 2005). Another source of progesterone are the adrenal glands, where its synthesis is under the control of adrenocorticotropic hormone (ACTH; Resko, 1969). As a consequence, the adrenal secretion of progesterone is increased in response to stress, and progesterone secretion by the adrenal glands can become comparable to that of the ovaries in stressed rats (Fajer et al., 1971; Schaeffer et al., 2008). In women, part of the circulating progesterone is derived from the adrenal glands, whereas in men, plasma progesterone is exclusively of adrenal origin (Gutai et al., 1977; Eldar-Geva et al., 1998). Progesterone carried in the bloodstream is bound to corticosteroid-binding globulin and albumin (Klieber et al., 2007). Free progesterone easily crosses the bloodbrain barrier and rapidly diffuses throughout the brain and spinal cord (Pardridge and Mietus, 1979).

However, progesterone is also a neurosteroid, which means that it is also synthesized within the nervous system. Thus, in addition to its endocrine mode of signaling, it acts on neural target cells via autocrine/paracrine mechanisms. The synthesis and metabolism of neurosteroids in the vertebrate nervous system have been extensively reviewed (Baulieu et al., 2001; Mellon and Vaudry, 2001; Do Rego et al., 2009; Pelletier, 2010). Progesterone synthesis involves conversion of cholesterol to pregnenolone by the side-chain-cleaving ( $\mathrm{scc}$ ) cytochrome P450scc, located at the inner mitochondrial membrane (Figure 2). The translocation of cholesterol from the outer to the inner mitochondrial membrane is mediated by the translocase $18 \mathrm{kDa}$ (TSPO), the former peripheral benzodiazepine receptor (Papadopoulos et al., 2006; Rupprecht et al., 2010). TSPO ligands can increase the biosynthesis of neurosteroids by stimulating the intra-mitochondrial transport of cholesterol, which is a rate-limiting step in pregnenolone synthesis. Pregnenolone is then converted to progesterone by a $3 \beta$ hydroxysteroid dehydrogenase ( $3 \beta-\mathrm{HSD})$, either in cytoplasm or mitochondria (Cherradi et al., 1995). Multiple 3 $\beta$-HSD isoforms have been isolated: six in mice, four in rats, and two in humans (Simard et al., 2005). However, most studies of $3 \beta$-HSD expression in the nervous system do not distinguish between the different isoforms and probes or antibodies recognize multiple isoforms. Progesterone is metabolized by two steroid $5 \alpha$-reductases to $5 \alpha$ dihydroprogesterone ( $5 \alpha$-DHP). The type 1 enzyme is expressed in the rat brain at all stages of development, whereas the type 2 enzyme shows a more restricted distribution (Melcangi et al., 1998; Patte-Mensah et al., 2004b). The same enzymes also reduce deoxycorticosterone to $5 \alpha$-dihydrocorticosterone and testosterone to $5 \alpha$-dihydrotestosterone.

$5 \alpha$-DHP is further metabolized by $3 \alpha$-hydroxysteroid oxidoreductases $(3 \alpha$-HSORs $)$ to allopregnanolone $(3 \alpha, 5 \alpha$ tetrahydroprogesterone) or by not well defined $3 \beta$-HSOR activities to epiallopregnanolone ( $3 \beta, 5 \alpha$-tetrahydroprogesterone). Whereas allopregnanolone is a positive allosteric modulator of $\mathrm{GABA}_{\mathrm{A}}$ receptors, the effect of epiallopregnanolone is inhibitory (Backstrom et al., 2005; Belelli and Lambert, 2005; Figure 2). The $3 \alpha$-HSOR activities involve two types of enzymes: (1) the NADPHdependent cytosolic aldo-keto reductases (AKRs), acting in vivo as 3-ketosteroid reductases and converting $5 \alpha$-DHP to allopregnanolone; (2) the $\mathrm{NAD}^{+}$-dependent membrane-associated shortchain dehydrogenases/reductases (SDRs), acting in vivo as $3 \alpha-$ hydroxysteroid oxidases and converting allopregnanolone back to 5 $\alpha$-DHP (Chetyrkin et al., 2001; Penning et al., 2004; Belyaeva et al., 2007; Penning, 2011). Whereas rats only have a single ARK isoform (AKR1C9), also named $3 \alpha$-HSD because it specifically converts 3-ketosteroids to $3 \alpha$-hydroxysteroids, multiple and less selective ARK isoforms are expressed in humans and mice (Penning et al., 2003; Ishikura et al., 2004). The epimerization of allopregnanolone to epiallopregnanolone is catalyzed by a $3(\alpha \rightarrow \beta)$ 


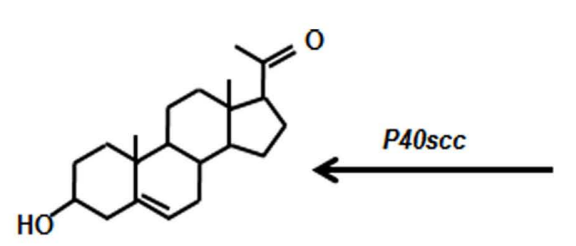

Pregnenolone

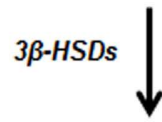<smiles>CC(=O)C1CCC2C3CCC4=CC(=O)CCC4(C)C3CCC12C</smiles>

Progesterone<smiles>CC(C)CCCC(C)C1CCC2C3CC=C4CC(O)CCC4(C)C3CCC12C</smiles>

Cholesterol<smiles>CC(=O)C1CCC2C3CC[C@H]4CC(=O)CCC4(C)C3CCC12C</smiles>

5a-dihydroprogesterone

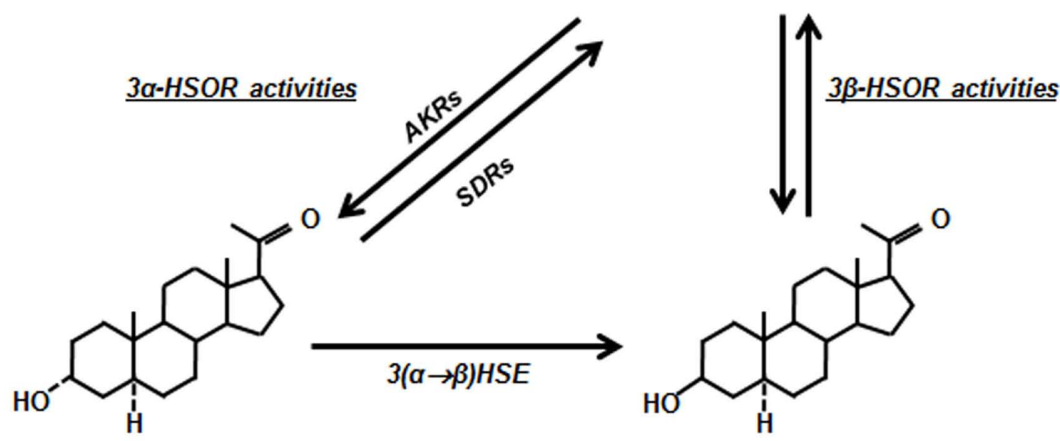

Allopregnanolone (3a,5a-tetrahydrogesterone)

Epiallopregnanolone (3 $\beta, 5 \alpha$-tetrahydrogesterone)

FIGURE 2 | Progesterone pathways. Cholesterol is converted to pregnenolone inside the mitochondria by cytochrome P450scc. Pregnenolone inside the mitochondria or in the cytoplasmic compartment is converted to progesterone by the $3 \beta$-hydroxysteroid dehydrogenases (3 $\beta$-HSDs). The conversion of progesterone to $5 \alpha$-dihydroprogesterone $(5 \alpha$-DHP) is catalyzed by two $5 \alpha$-reductase isoforms. $5 \alpha$-DHP can be metabolized to allopregnanolone ( $3 \alpha, 5 \alpha$-tetrahydroprogesterone) by $3 \alpha$-hydroxysteroid oxidoreductase ( $3 \alpha$-HSORs) activities, involving aldo-keto reductases (AKRs) converting $5 \alpha$-DHP to allopregnanolone and short-chain dehydrogenases/reductases (SDRs), converting allopregnanolone back to $5 \alpha$-DHP. A $3(\alpha \rightarrow \beta)$ hydroxysteroid epimerase (HSE) catalyzes the epimerization of allopregnanolone into epiallopregnanolone. hydroxysteroid epimerase (HSE). It most likely involves two successive enzymatic steps: the oxidation of the $3 \alpha$-hydroxyl group followed by the reduction of the 3-ketone group to a $3 \beta$-hydroxyl group (Higashi et al., 2004; Belyaeva et al., 2007; Figure 2).

Neural progesterone synthesis was first described in glial cell cultures prepared from neonatal rat brains (Jung-Testas et al., 1989). Astrocytes in culture were also reported to synthesize neurosteroids (Mellon and Deschepper, 1993). On the basis of these observations, it was assumed that neurosteroids within the brain would be mainly formed by glial cells. However, it became rapidly evident that progesterone is also synthesized by CNS neurons. Thus, in the frog hypothalamus, $3 \beta$-HSD immunoreactivity was exclusively found in neurons (Mensah-Nyagan et al., 1994). In the rat brain, Purkinje neurons were identified as a major site of progesterone formation, and to express both cytochrome P450scc and 3 $\beta$-HSD enzymes (Ukena et al., 1998, 1999). Neurons, astrocytes, and oligodendrocytes isolated from neonatal rat brains were all shown to express both P450scc and $3 \beta-\mathrm{HSD}$ enzymes and to produce pregnenolone and progesterone (Zwain and Yen, 1999). Moreover, expression studies of neurosteroidogenic enzymes have revealed their wide distribution throughout the rat brain (Compagnone and Mellon, 2000).

Expression of $5 \alpha$-reductase type 1 and $3 \alpha$-HSD mRNA has been analyzed in detail in the mouse brain, where both enzymes were shown to colocalize in principal glutamatergic neurons of the cerebral cortex, hippocampus, olfactory bulbs, and in glutamatergic output neurons of the thalamus and amygdala. Both enzymes are also present in GABAergic output neurons of the striatum and thalamus as well as in cerebellar Purkinje neurons, consistent with an autocrine/paracrine modulation of $\mathrm{GABA}_{\mathrm{A}}$ receptor signaling by locally produced neurosteroids. Surprisingly, none of the enzymes was detected in astrocytes, considered to be a major source of neurosteroids (Agis-Balboa et al., 2006). However, another study reported the presence of the two $5 \alpha$-reductase 
enzyme isoforms and the unique $3 \alpha-\mathrm{HSD}$ (AKR1C9) in neurons, astrocytes, and oligodendrocytes of the adult rat spinal cord, suggesting that allopregnanolone may also be synthesized by glial cells (Patte-Mensah et al., 2004b).

The synthesis of progesterone from its direct precursor pregnenolone, and its metabolism to $5 \alpha$-DHP, allopregnanolone, and epiallopregnanolone, have been analyzed at three major stages of rat oligodendrocyte maturation described above: early OPP, OPC, and fully differentiated oligodendrocytes (Figure 1B). In this study, important differences in progesterone synthesis and metabolism were observed between the different developmental stages, strongly suggesting that progestagens may play an important role in the generation of new oligodendrocytes and in myelination (Gago et al., 2001). Both early OPP and OPC, but not the mature oligodendrocytes produced significant amounts of progesterone. In contrast, in oligodendrocytes, the conversion of progesterone to $5 \alpha$-DHP by the type 1 isoform of the $5 \alpha$-reductase was highest. These results indicate that adult oligodendrocytes actively metabolize progesterone derived from the circulation or other neural cells to $5 \alpha$-DHP, which may play a role in the regulation of oligodendroglial functions and in the maintenance of myelin. They are also consistent with earlier reports of a very high $5 \alpha$-reductase activity in cultured oligodendrocytes and in brain white matter (Melcangi et al., 1988, 1994; Celotti et al., 1992). The further metabolism of $5 \alpha$-DHP to allopregnanolone was about 10 times higher in the early OPP when compared to the other developmental stages (Gago et al., 2001).

Extensive mapping of $3 \beta$-HSD mRNA in the rat brain by in situ hybridization revealed its large distribution throughout the brain in neuronal populations of the olfactory bulb, hypothalamus, septum, striatum, thalamus, habenula, hippocampus, cerebral cortex, and cerebellum. Nucleotide sequencing of PCR-amplified cDNA fragments indicated expression of $3 \beta$-HSD isoform 1 (Guennoun et al., 1995). Another in situ hybridization study of the developmental expression and localization of $3 \beta-\mathrm{HSD}$ in the rat brain confirmed the wide distribution of the enzyme in neurons the day of birth and on postnatal days 7, 14, and 70. Quantitative in situ hybridization analysis within the hippocampus revealed a decrease in the expression of $3 \beta$-HSD mRNA expression with progressing age, concomitant with a decrease in hippocampal progesterone levels measured by gas chromatography/mass spectrometry (GC/MS; Ibanez et al., 2003a). The enzyme is also strongly expressed in neurons throughout the rat spinal cord, in the large ventral horn motoneurons and in the small dorsal horn neurons (Coirini et al., 2002).

The above described changes in progesterone synthesis and metabolism during the maturation of oligodendrocytes, and the age-dependent modifications of hippocampal 3 $\beta$-HSD expression and progesterone levels raise the question of the synthesis and significance of neurosteroids during brain development. Although there is strong experimental evidence for an important role of neuroprogesterone in brain development, data are still fragmentary, and a coherent picture is still missing. It is indeed difficult to distinguish between the effects of progesterone synthesized by the brain, placenta, or developing gonads and adrenal glands.

Nevertheless, the synthesis and role of neurosteroids in the developing CNS are an expanding field of interest and have been recently reviewed (Tsutsui et al., 2004; Mellon, 2007; Hirst et al., 2008). Although an exhaustive appraisal of the significance of neurosteroids during brain development is beyond the scope of this review, some key observations warrant to be discussed. Interestingly, enzymes involved in the synthesis and metabolism of progesterone are present in the nervous system from embryonic life to adulthood, where they are expressed in a region-specific manner (Compagnone and Mellon, 2000; Mellon, 2007). Thus, $\mathrm{P} 450 \mathrm{scc}$ protein has been detected by immunocytochemistry as early as embryonic day 9.5 in the rat nervous system (Compagnone et al., 1995). It has been proposed that progesterone and its reduced metabolites, produced either by the placenta or within the brain, may have a neuroprotective role during fetal and neonatal life, when complications or low oxygen can lead to brain injury with serious long-term consequences for the neonate. Indeed, both cytochrome P450scc and $5 \alpha$-reductase enzymes are upregulated and levels of allopregnanolone are increased within vulnerable regions of the developing sheep brain in response to hypoxia (Nguyen et al., 2003; Hirst et al., 2008). Moreover, endogenous $5 \alpha$-reduced metabolites of progesterone provide resistance to brain damage, as neuron death in the hippocampus resulting from hypoxia is markedly increased after infusion of the $5 \alpha$-reductase inhibitor finasteride (Yawno et al., 2007).

In cerebellar Purkinje neurons, P450scc expression starts immediately after their differentiation around birth (Ukena et al., 1998). During the neonatal period, Purkinje neurons also synthesize progesterone and allopregnanolone, and $3 \beta-\mathrm{HSD}$ expression and activity are highest in the cerebellum between 7 and 14 days of age (Ukena et al., 1999). At this developmental stage, progesterone promotes dendritic growth and synaptogenesis in the developing Purkinje cells via PR signaling (Sakamoto et al., 2001; Tsutsui et al., 2004). Brain levels of allopregnanolone vary considerably across development in rats as a result of changes in $5 \alpha$-reductase and $3 \alpha-H S D$ expression, with very high levels at birth followed by steady low levels until adulthood (Grobin et al., 2003; Griffin et al., 2004). The administration of allopregnanolone to rat pups at specific stages results in marked changes in cortical cytoarchitecture and in behavior (Grobin et al., 2006). In a mouse model of Niemann-Pick type C disease, brain $5 \alpha$-reductase, and $3 \alpha$-HSD activities and allopregnanolone levels were markedly decreased during postnatal life. Importantly, the replacement of allopregnanolone alleviated and delayed some of the neurodegenerative features of the disease (Griffin et al., 2004).

Important for our purpose is the observation that hypoxia during pregnancy also leads to devastating white matter damage, as OPC and immature oligodendrocytes are particularly vulnerable (Back et al., 2002). A marked rise in allopregnanolone levels has been observed in dialysate probes of sheep white matter after hypoxia, and it has been proposed that this response may be part of endogenous protective mechanisms (Nguyen et al., 2004; Hirst et al., 2008). As discussed later, progestagens play a key role in myelin formation during development.

This rapid and non-exhaustive overview of experimental evidence for the local synthesis of neuroprogesterone within the CNS requires some cautious considerations. Although taken as a whole, available experimental data provide convincing evidence that progesterone can be synthesized by neural cells, both in the 
adult and developing nervous system, individual studies often reveal large gaps, and results should always be interpreted within their precise context. Thus, the expression and activity of steroidogenic enzymes are subject to complex regulations, and they may be expressed and functional in a defined compartment of the nervous system only under particular conditions, depending on environmental influences, cellular interactions, the presence of neurotransmitters or neuropeptides, the developmental stage, or the integrity of the nervous tissue (Do Rego et al., 2009). It is also important to be aware of some technical constraints. Thus, the relevance of studies on the formation of neurosteroids by cultured neural cells isolated from embryonic or newborn animals needs to be verified in vivo because of the phenotypic plasticity these cells can exhibit in vitro. Also, although studies limited to the expression of steroidogenic enzymes by in situ hybridization, reverse transcriptase-polymerase chain reaction or immunocytochemistry provide valuable information, they do not demonstrate their functionality.

Additional support for the synthesis and biological significance of progesterone and its metabolites within the CNS has been provided by in vivo studies. Thus, elevated levels of pregnenolone and progesterone can be measured in the male rat CNS after removal of the steroidogenic endocrine glands by castration and adrenalectomy, consistent with their endogenous production (Coirini et al., 2002). It could be argued that the long-term persistence of steroids in the brain of adrenalectomized and castrated animals may simply reflect retention and accumulation of the lipophilic compounds. However, a series of studies have demonstrated that levels of pregnenolone, progesterone, and allopregnanolone can be increased in the brains of rats deprived of their steroidogenic endocrine glands by the administration of TSPO ligands (Korneyev et al., 1993; Romeo et al., 1993; Serra et al., 1999; Bitran et al., 2000; Verleye et al., 2005). These findings show that it is possible to stimulate the synthesis of neurosteroids in the brain.

Importantly, levels of pregnenolone and progesterone were significantly increased in the male rat spinal cord in response to injury, even in castrated and adrenalectomized rats with undetectable plasma levels of the hormones (Labombarda et al., 2006). Brain levels of progesterone are also transiently upregulated in response to TBI, in brain regions proximal, and distal to the lesion site (Meffre et al., 2007a). In the rat spinal cord, 3 $\beta$ HSD mRNA expression was upregulated and the conversion of pregnenolone to progesterone was markedly increased 3 months after streptozotocin-induced diabetes (Saredi et al., 2005). The de novo synthesis of neurosteroids has also been demonstrated in pain pathways, where progesterone and allopregnanolone play an important role (Mensah-Nyagan et al., 2009). Thus, during neuropathic pain provoked by sciatic nerve ligature, P450scc was over-expressed in spinal and supra-spinal pain networks, concomitant with an increase pregnenolone and allopregnanolone synthesis (Patte-Mensah et al., 2004a). Increased levels of progesterone and $3 \beta$-HSD expression were also observed within the brains of dysmyelinating jimpy and shiverer mouse mutants (Le Goascogne et al., 2000). Taken together, these findings strongly suggest that increased progesterone synthesis in the CNS may be part of endogenous neuroprotective mechanisms and may correspond to a physiological response of neural cells to injury and degenerative conditions (De Nicola et al., 2009). In addition, neuroprogesterone synthesis also shows physiological changes, as for example during the estrous cycle (Soma et al., 2005).

A major limitation for detecting local changes in brain steroid levels within a particular physiological or pathological context is the limited sensitivity of the available analytical methods, either radioimmunoassay or mass spectrometry coupled to either liquid or gas chromatography (Liere et al., 2000). Indeed, the amount of brain tissue required to accurately analyze low levels of neurosteroids (about 50-100 mg) corresponds to very large numbers of neural cells (about 35,000 cells per $\mathrm{mg}$ ), thus precluding the detection of localized changes (Geisert et al., 2002; Azevedo et al., 2009). Unfortunately, no analytical procedure allows to measure changes in neurosteroid levels within small populations of neurons or at the synaptic level. Similarly, the measure of enzymatic activities requires the incubation of large amounts of tissue with precursor steroids.

A particularly sensitive experimental approach to examine the significance of local changes in brain steroids within a particular physiological and pathophysiological context is the combination of electrophysiological recordings with the inhibition or stimulation of neurosteroid biosynthetic pathways. Such studies have in fact provided strong evidence for an important role of the local brain metabolism of steroids in the regulation of neuronal functions, and in particular for the role of neurosteroids as endogenous autocrine/paracrine modulators of $\mathrm{GABA}_{\mathrm{A}}$ receptors. They also suggest the presence of endogenous neurosteroid tones within specific brain regions (Lambert et al., 2009). In most of these studies, the measure of inhibitory postsynaptic currents (IPSCs) was used to evaluate the influence of locally synthesized $3 \alpha, 5 \alpha$ neurosteroids on $\mathrm{GABA}_{\mathrm{A}}$ receptor activity. Thus, the systemic administration of the $5 \alpha$-reductase inhibitor SKF105111 in mice reduced the decay of miniature IPSCs recorded from cortical neurons (Puia et al., 2003). The application of the $3 \alpha-H S D$ inhibitors medroxyprogesterone acetate $(\mathrm{MPA}=$ Provera) or indomethacin to rat hippocampal slices uncovered a neurosteroid tone in dentate gyrus granule cells, enhancing the activity of both synaptic and extrasynaptic GABAA receptors (Belelli and Herd, 2003). During postnatal development, TSPO-mediated synthesis of $3 \alpha, 5 \alpha-$ reduced neurosteroids within specific lamina of the rat spinal dorsal horns results in miniature IPSCs with slow decay kinetics. Importantly, this inhibitory neurosteroid tonus is reactivated in the adult spinal cord in response to peripheral inflammation, when it is involved in analgesic processes (Keller et al., 2004; Inquimbert et al., 2008). Stimulation of neurosteroid synthesis with the selective TSPO agonist XBD173 enhanced both the amplitude and duration of evoked IPSCs recorded from neurons of the medial prefrontal cortex, and this effect could be blocked by the $5 \alpha$-reductase inhibitor finasteride (Rupprecht et al., 2009). The in vivo efficacy of some TSPO ligands at increasing brain levels of allopregnanolone, a neurosteroid with anxiolytic properties, has generated interest in their therapeutic potential for the treatment of anxiety disorders (Verleye et al., 2005; Rupprecht et al., 2009, 2010). However, allopregnanolone displays a broad spectrum of psychopharmacological properties. Thus, an increase in its brain, cerebrospinal fluid, and plasma levels of allopregnanolone in response to fluoxetine (Prozac ${ }^{\circledR}$ ) treatment has been proposed 
to play a role in the antidepressant actions of the drug (Uzunova et al., 2006).

An interesting example of neurosteroid-dependent neuronal plasticity and regulation of inhibitory inputs to neurons has been reported for the auditory midbrain. After selectively blocking the GABAergic innervation of the central nucleus of the inferior colliculus by afferents of the dorsal nucleus of the lateral lemniscus, enhanced local production of allopregnanolone provided compensation by increasing the efficacy of the other inhibitory inputs (Saalmann et al., 2006).

Over the past few years, evidence has accumulated that progesterone and its metabolites are also synthesized in the human nervous system (Stoffel-Wagner, 2001; Weill-Engerer et al., 2002; Schumacher et al., 2003). The presence of cytochrome P450scc was first detected in the human brain by immunocytochemistry (Le Goascogne et al., 1989), and subsequently several studies have described the presence of cytochrome P450scc mRNA in different brain regions (Beyenburg et al., 1999; Watzka et al., 1999; Inoue et al., 2002; Yu et al., 2002). The type II isoform of the human $3 \beta$-HSD is largely expressed in different parts of the brain and spinal cord (Inoue et al., 2002; Yu et al., 2002). Also, the enzymes necessary for the metabolism of progesterone are present in the human brain (Steckelbroeck et al., 2001; Stoffel et al., 2003).

\section{SOURCES OF PROGESTERONE IN THE PERIPHERAL NERVOUS SYSTEM}

Progesterone present in the bloodstream also crosses the bloodnerve barrier and easily reaches neural cells in peripheral nerves and dorsal root ganglia (DRG). In addition, there is also evidence for neuroprogesterone synthesis by neurons and Schwann cells in the PNS. Thus, levels of pregnenolone were found to be higher in male rat sciatic nerves than in plasma, and they were not reduced by castration and adrenalectomy, strongly suggesting a local synthesis of the direct precursor of progesterone independent of glandular sources. Cultured Schwann cells isolated from neonatal rat sciatic nerves indeed converted 25-hydroxycholesterol, a cholesterol metabolite which easily crosses cell membranes, to pregnenolone (Akwa et al., 1993).

As for the CNS, potential links between neurosteroidogenesis and myelination have been reported for the PNS. Thus, cytochrome P450scc and 3 $\beta$-HSD mRNA were found to be markedly upregulated in myelinating cocultures of DRG neurons and Schwann cells, but they were exclusively observed in Schwann cells (Chan et al., 1998, 2000). It was then shown, by using different coculture systems, that $3 \beta$-HSD expression and progesterone synthesis by Schwann cells are dependent on the presence of neurons. Indeed, levels of $3 \beta$-HSD mRNA and the conversion of $\left[{ }^{3} \mathrm{H}\right]$ pregnenolone to $\left[{ }^{3} \mathrm{H}\right]$ progesterone were extremely low in purified Schwann cells prepared from neonatal rat sciatic nerves. However, $3 \beta$-HSD expression and activity were markedly induced in Schwann cells by the presence of DRG neurons (Robert et al., 2001). Interestingly, a direct contact with sensory neurons was not required for the induction of progesterone synthesis in Schwann cells, but a diffusible neuronal factor was sufficient. This was demonstrated by using a coculture system in which Schwann cells and sensory neurons were cultured together, but separated by a microporous membrane. Interestingly, the induction of $3 \beta-H S D$ in Schwann cells by a diffusible neuronal signal was very slow and became maximal only after 18 days of coculture (Robert et al., 2001).

Although the diffusible factor has not been identified, it was neuron-specific as neither the presence of fibroblasts, nor of a human liver cell line, induced $3 \beta$-HSD expression in Schwann cells. However, although a diffusible neuronal signal was sufficient to induce progesterone and $5 \alpha$-dihydroprogesterone synthesis in Schwann cells, the formation of allopregnanolone required a direct contact with DRG neurons. Thus, both diffusible and contactmediated interactions between Schwann cells and neurons are involved in the regulation of neurosteroid formation. This is consistent with the previously reported regulation of Schwann cell functions by neurons either via direct contact or diffusible molecules (Bolin and Shooter, 1993).

A role of neurons in the regulation of $3 \beta-\mathrm{HSD}$ expression was also demonstrated in vivo in the rat sciatic nerve. While $3 \beta-\mathrm{HSD}$ mRNA was present in the intact nerve, it could no longer be detected 3 or 6 days after cryolesion, when axons had degenerated. After 15 days, when Schwann cells established new contacts with the regenerating axons, the enzyme was again re-expressed. After nerve transection, which does not allow axonal regeneration, $3 \beta$ HSD mRNA remained undetectable. Importantly, the regulation of $3 \beta$-HSD mRNA after sciatic nerve lesion paralleled the expression of P0 and PMP22 mRNA, supporting an important role of locally formed progesterone in myelination (Robert et al., 2001). As Schwann cells not only synthesize progesterone, but also express the intracellular PR, the neurosteroid may be part of autocrine regulatory mechanisms involved in myelination (Jung-Testas et al., 1996).

Schwann cells are not the only source of progesterone in the PNS. Indeed, sensory neurons isolated from embryonic rat DRG also express the $3 \beta$-HSD and convert $\left[{ }^{3} \mathrm{H}\right]$ pregnenolone to $\left[{ }^{3} \mathrm{H}\right]$ progesterone. Moreover, when cultured under different conditions, DRG neurons produced about 5-10 times more progesterone than Schwann cells (Guennoun et al., 1997). Under the experimental conditions tested, DRG neurons further metabolized progesterone to $5 \alpha$-dihydroprogesterone, but unlike Schwann cells, they did not produce allopregnanolone. Neurons and Schwann cells purified from the DRG of 6 week-old-male rats showed a similar pattern of pregnenolone and progesterone metabolism than cells isolated from 18-day-old embryos. The activity of the $3 \beta$-HSD has been characterized in homogenates prepared from adult rat sciatic nerves by quantifying the conversion of $\left[{ }^{3} \mathrm{H}\right]$ pregnenolone to $\left[{ }^{3} \mathrm{H}\right]$ progesterone. The calculated $K \mathrm{~m}$ value of $3 \beta$-HSD activity was about $1 \mu \mathrm{M}$, thus close to the values reported for the $3 \beta$-HSD type 1 isoform (Coirini et al., 2003a,b).

The absence of allopregnanolone formation by embryonic DRG neurons in culture contrasts with immunocytochemical in vivo observations of the $3 \alpha-\mathrm{HSD}$ in both DRG neurons and Schwann cells. Moreover, allopregnanolone is synthesized in DRG, and its production is increased in response to sciatic nerve constriction injury, consistent with an important role of locally produced allopregnanolone in the regulation of nociceptive functions. Thus, during the development of inflammatory pain, increased formation of allopregnanolone in lamina II of the spinal dorsal 
horn increased synaptic inhibition mediated by $\mathrm{GABA}_{\mathrm{A}}$ receptors and limited thermal hyperalgesia, but not mechanical allodynia (Poisbeau et al., 2005). Furthermore, inhibition of $3 \alpha$-HSD expression in DRG exacerbated thermal and mechanical pain perceptions (Patte-Mensah et al., 2010). Allopregnanolone may be synthesized de novo from cholesterol within DRG, as a functional P450scc enzyme is present and upregulated in response to neuropathic pain (Patte-Mensah et al., 2003).

\section{STIMULATION OF PERIPHERAL MYELINATION BY PROGESTERONE}

A role of progesterone and its local synthesis in myelin repair has been shown in the regenerating mouse sciatic nerve after cryolesion (Koenig et al., 1995; Table 1). In response to local freezing, axons and their accompanying myelin sheaths rapidly degenerate within the frozen zone and in the segment distal to the lesion site by a process known as "Wallerian degeneration." It is now well established that the degeneration of peripheral axons in response to injury is an active process, corresponding to an active axon destruction program distinct from apoptosis (Coleman and Freeman, 2010). However, whereas axons degenerate after cryolesion of the sciatic nerve, the basal lamina tubes remain intact, and provide an appropriate environment and support for rapid regeneration of the damaged nerve fibers. In the zone of freeze injury, Schwann cells start remyelinating the regenerating axons within 1 week, and after 2 weeks, the myelin sheaths reach approximately one-third of their final size. During this period, local application of the $3 \beta-H S D$ inhibitor trilostane or the PR antagonist mifepristone (RU486) to the regenerating nerve fibers inhibited their remyelination. The inhibitory effect of trilostane could be reversed by the simultaneous administration of progesterone, thus demonstrating a role of locally synthesized progesterone in myelin formation. Moreover, myelination of axons was increased when progesterone was added to DRG explant cultures (Koenig et al., 1995). Later, it was shown that adding progesterone to cocultures of Schwann cells and neurons enhances the rate of myelin formation (Chan et al., 1998).

In myelinating cocultures of Schwann cells and DRG neurons, PR immunostaining was only detected in the neurons, and adding progesterone to the culture medium induced neuronspecific genes. These observations suggested that progesterone may indirectly stimulate Schwann cell myelination by acting on neurons (Chan et al., 2000). Such an indirect signaling mechanism would not be further surprising, as the formation of myelin sheaths is tightly controlled by axonal signals in the PNS. It is however likely that progesterone promotes myelination by acting on multiple cellular targets, and also directly on Schwann cells. Progesterone has indeed been shown to activate the promoters of peripheral myelin genes in purified cultures of Schwann cells isolated form neonatal rat sciatic nerves (Désarnaud et al., 1998). In this study, Schwann cells were transiently transfected with reporter constructs in which luciferase expression was controlled by the promoter regions of either the PO or PMP22 gene. Expression of the $P M P 22$ gene is driven by two alternate promoters $P 1$ and $P 2$, of which only the first is involved in myelination (Suter et al., 1994). Under our experimental conditions, progesterone stimulated the promoter of $P O$ and promoter $P 1$, but not promoter
P2, of PMP22. In addition to this promoter selectivity, the effect of progesterone was steroid-specific, as it could be mimicked by the selective PR agonist ORG 2058, but neither by estradiol nor testosterone. Moreover, progesterone activated the myelin gene promoters when they were transfected into Schwann cells, but into human T47D breast cancer cells, in spite the fact that this cell line constitutively expresses high levels of functional PR. Taken together, the promoter-, steroid-, and cell-specificity suggests that the transcriptional effects of progesterone on PMP genes may be of physiological relevance (Désarnaud et al., 1998).

The observation that the selective progestin ORG 2058 stimulated $P 0$ and $P M P 22$ promoter activities is consistent with an important role of the PR. In primary cultures of purified neonatal rat Schwann cells, the presence of the PR was indeed detected by whole cell binding assays with $\left[{ }^{3} \mathrm{H}\right] \mathrm{ORG} 2058$ and by immunocytochemistry (Jung-Testas et al., 1996). However, in another study, no significant PR expression and activity could be measured in rat Schwann cells kept for a long time in culture, as well as in various Schwann cell lines (Groyer et al., 2006). The discrepancy between these results could be explained by a tightly regulated expression of PR in Schwann cells. Thus, steroid receptor expression in purified Schwann cells decreases with time (unpublished observation). Also, PR are inducible by estrogen in Schwann cells cultured together with DRG neurons, but not in purified cultures of Schwann cells (Jung-Testas et al., 1996; Thi et al., 1998). However, detecting receptor mRNA, protein or ligand binding is not sufficient to conclude that a receptor is functional. Indeed, low levels of steroid receptors may not be sufficient to trigger biological activity, and threshold levels of expression may be required for steroid responsiveness (Okret et al., 1991). Defining the precise role of the Schwann cell PR in vivo will require its cell-specific and conditional inactivation.

Another important question is whether the $P 0$ and PMP22 genes are direct targets of progesterone, or whether other PR target genes mediate the promyelinating effects of the hormone. It has indeed been proposed that progesterone may indirectly activate the $P 0$ and $P M P 22$ promoters, as no progesterone response elements (PRE/GRE) were identified in their sequences (Désarnaud et al., 1998). However, it is always difficult to exclude the involvement of responsive DNA sites in the effects of steroids, and the presence of two sequences within the $\mathrm{P} 0$ promoter region presenting about $40 \%$ homology with consensus PRE/GRE has been reported, although their functionality has not been tested (Magnaghi et al., 1999). Whatever, in the light of recent advances in our understanding of PR-dependent regulation of gene expression, the question of the presence or absence of hormone response elements within myelin genes or their promoter regions is no longer relevant. Thus, $\mathrm{PR}$ can regulate gene transcription by binding to very remote cis-regulatory sites and act at long distances (Deblois and Giguere, 2008). Alternatively, PR may alter gene expression by non-classical mechanisms, either by tethering with other nuclear transcription factors or by interacting with extra-nuclear kinases (Daniel et al., 2009).

Expression of $P O$ has been shown to be increased by progesterone and $5 \alpha$-dihydroprogesterone treatment in the sciatic nerve in vivo and in cultured Schwann cells. On the contrary, the expression of PMP22 was found to be stimulated by the progesterone 
Table 1 | Effects of progestagens on myelination/remyelination.

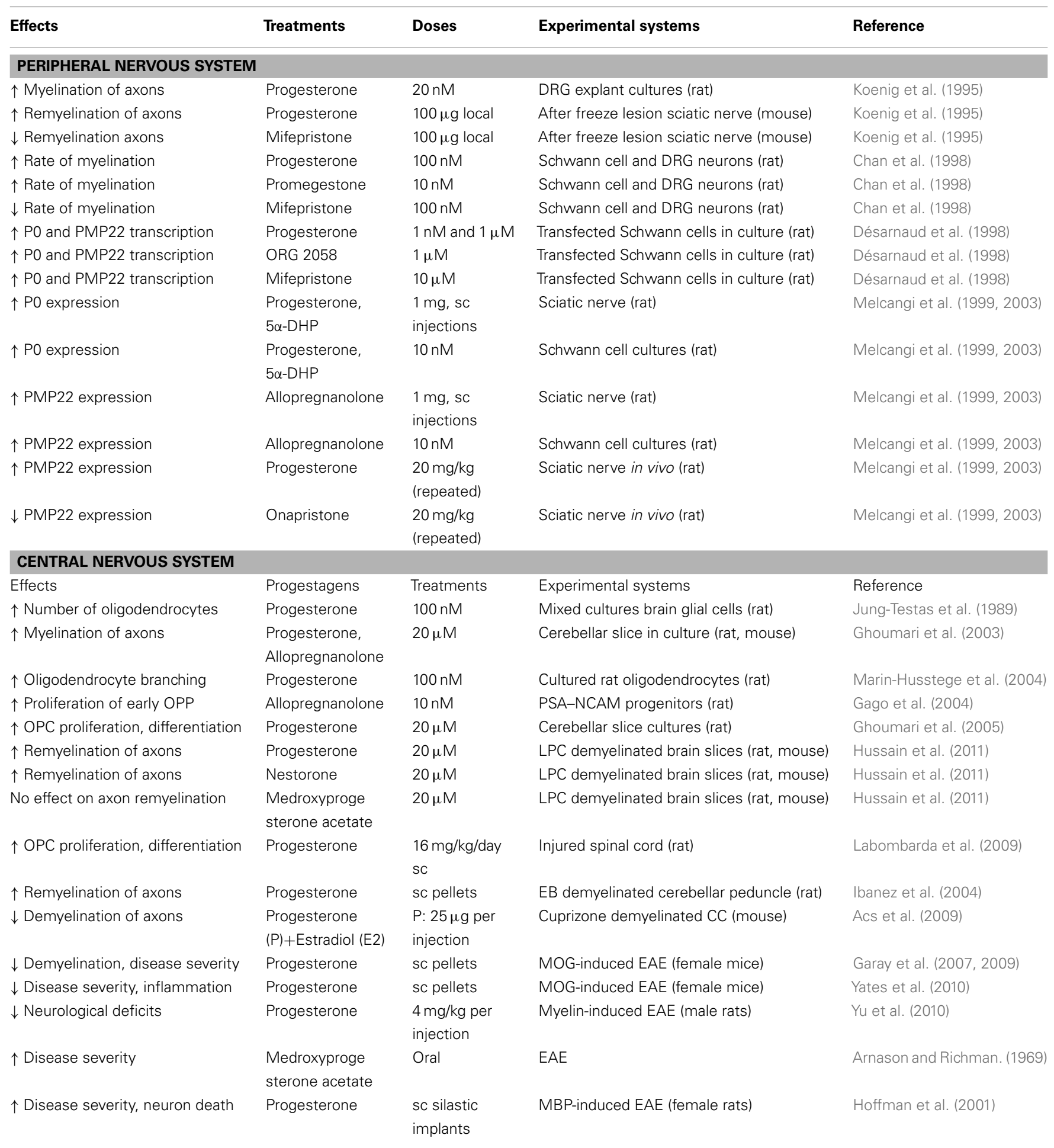

$C C$, corpus callosum; DRG, dorsal root ganglia; EAE, experimental autoimmune encephalomyelitis; EB, Ethidium bromide, DNA intercalating agent, kills cells but spares axons; LPC, lysophosphatidylcholine, kills oligodendrocytes but spares axons; Medroxyprogesterone acetate (MPA, Provera): progestin, pregnane, non-selective PR agonist; Mifepristone (RU486): selective progesterone receptor modulator (SPRM), also antagonist of the glucocorticoid receptor; MOG, myelin oligodendrocyte glycoprotein; Nestorone: progestin, 19-norpregnane, PR agonist; Onapristone (ZK 98299): selective PR antagonist; ORG 2058: progestin, PR agonist; Promegestone (R5020): progestin, 19-norpregnane, PR agonist; sc, subcutaneous. 
metabolite allopregnanolone acting via $\mathrm{GABA}_{\mathrm{A}}$ receptors under the same experimental conditions (Melcangi et al., 1999, 2003, 2005; Table 1). Adding to the complexity of myelin gene regulation, glucocorticoids have also been shown to activate both $P 0$ and PMP22 promoters (Désarnaud et al., 2000). As already mentioned, myelin protein genes are dosage-sensitive and require tightly coordinated expression. It is difficult to understand how this could be achieved if different genes would be directly and independently targeted by multiple hormones. It is thus appealing to propose indirect steroidal influences on myelin formation, involving a master regulatory signaling pathway for the coordinated expression of myelin genes.

In a transgenic rat model of CMT1A overexpressing PMP22, PR signaling was shown to enhance the disease phenotype. Indeed, progesterone treatment further increased PMP22 mRNA levels and had adverse effects on disease symptoms, whereas administration of the selective PR antagonist onapristone normalized PMP22 expression and improved the CMT1A phenotype. These data suggest that the Schwann cell PR may be a promising pharmacological target for the therapy of CMT1A (Sereda et al., 2003). Interestingly, it was then shown that long-term anti-progestin treatment of CMT1A rats prevents axonal loss, which is characteristic of the neuropathy, but in the absence of a beneficial influence on myelin. Thus, Schwann cell defects can result in axon damage independent of myelin loss (Meyer zu Horste et al., 2007).

\section{STIMULATION OF CENTRAL MYELINATION BY PROGESTERONE}

As reported above, early OPP synthesize progesterone and produce its reduced metabolite allopregnanolone, a potent positive allosteric modulator of $\mathrm{GABA}_{\mathrm{A}}$ receptors. Progesterone indeed indirectly stimulates the proliferation of early OPP through its metabolite allopregnanolone via a bicuculline-sensitive mechanism involving $\mathrm{GABA}_{\mathrm{A}}$ receptors (Gago et al., 2004). Importantly, the early OPP express $\mathrm{GABA}_{\mathrm{A}}$ receptors and also synthesize GABA. These results reveal complex autocrine/paracrine loops in the control of early OPP proliferation, involving interactive neurosteroid and GABA signaling (Figure 3).

In organotypic slice cultures of 7-day-old rat cerebellum, progesterone was found to also stimulate the proliferation of OPC at later stages of maturation, when they become OPC expressing the chondroitin sulfate proteoglycan NG2 and pre-oligodendrocytes co-expressing both NG2 and O4 antigens (Ghoumari et al., 2005; Table 1). Contrary to the early OPP, progesterone stimulated the proliferation of pre-oligodendrocytes via a PR-dependent mechanism, as its mitogenic effect was inhibited by the PR antagonist mifepristone and could not be mimicked by allopregnanolone, even at a high concentration (Ghoumari et al., 2005). There may thus be a developmental shift in mitogenic signaling: allopregnanolone acting via $\mathrm{GABA}_{\mathrm{A}}$ receptors in early OPP and progesterone acting via intracellular $\mathrm{PR}$ in pre-oligodendrocytes. However, it remains to be clarified whether progesterone exerts its mitogenic effects by directly acting on pre-oligodendrocytes in the cerebellar slices, or indirectly by acting on neurons or astrocytes. Myelination is indeed influenced by a crosstalk between neurons and oligodendrocytes and is dependent on axonal functions (Trapp and Nave, 2008). In this context, it is interesting to

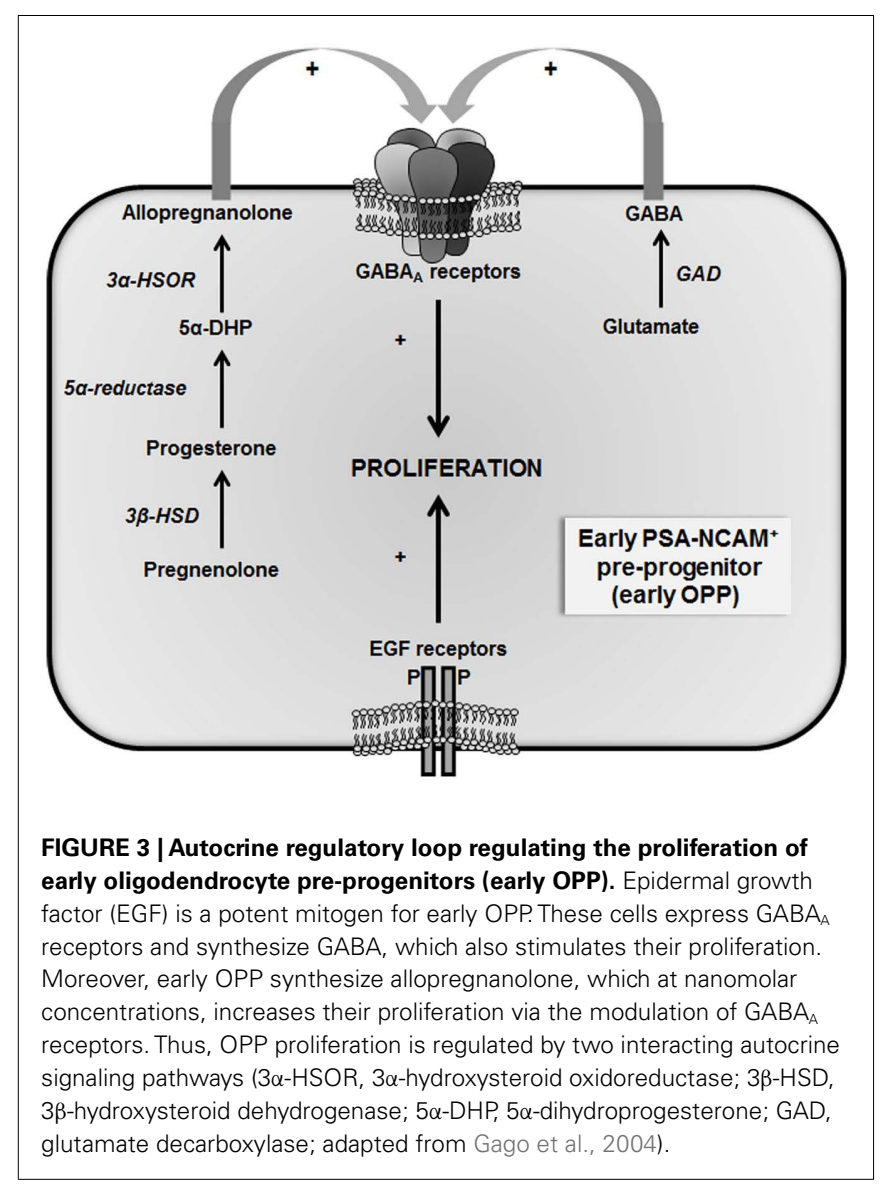

remind the neuroprotective functions of progesterone and allopregnanolone and their regenerative potential (Wang et al., 2008). Astrocytes are also particularly interesting targets of progesterone, as progesterone stimulates growth factor production by these cells via PR signaling (Lacroix-Fralish et al., 2006; Chesik and De, 2010).

Interestingly, between 3 and 7 days in culture, a drop in the number of the $\mathrm{NG}^{+} / \mathrm{O} 4^{+}$pre-oligodendrocytes in the cerebellar slice cultures was associated with a marked increase in $\mathrm{O}^{+} / \mathrm{GalC}^{+}$ premyelinating and myelinating oligodendrocytes. This observation suggests that progesterone may not only stimulate the proliferation of progenitor cells, but also their differentiation into mature oligodendrocytes (Ghoumari et al., 2003, 2005).

That progesterone indeed promotes the differentiation of OPC into myelinating oligodendrocytes has been recently demonstrated in adult male rats after spinal cord injury (Labombarda et al., 2009). Oligodendrocytes are very sensitive to different types of insults, and their loss followed by the demyelination of axons is a hallmark of CNS injury (Lytle and Wrathall, 2007; Siegenthaler et al., 2007). Three days after spinal cord transection, the number of oligodendrocytes was reduced by half, accompanied by a concomitant marked increase in the number of OPC. Shortly after injury, progesterone treatment further increased the number of OPC and stimulated their proliferation as determined by the incorporation of bromodeoxyuridine (BrdU). The differentiation of OPC which had incorporated BrdU during the first 3 days after injury was examined after 21 days by analyzing 
the colocalization of retained BrdU and myelin-specific markers. This window-labeling strategy allowed demonstrating that progesterone is required for the differentiation of OPC into oligodendrocytes (Labombarda et al., 2009). Indeed, in the absence of progesterone treatment, OPC failed to differentiate into oligodendrocytes after spinal cord injury.

A role of progesterone in OPC differentiation and myelin protein gene expression is a major finding, as compromised remyelination observed at advanced stages of multiple sclerosis may be caused by defective OPC maturation, rather than by impaired OPC recruitment (Franklin and Kotter, 2008). Whether the differentiating effect of progesterone on OPC reflects direct actions or is indirectly mediated via other cell types remains to be clarified. Indeed, after spinal cord injury, progesterone not only stimulates the generation of new oligodendrocytes but has also a beneficial influence on astrogliosis and neuroinflammatory responses (Labombarda et al., 2011).

Then, the important question arises whether the effects of progesterone on OPC proliferation and differentiation translate into increased myelin formation and improved axon remyelination. The effects of progesterone on developmental myelination were again investigated in slice cultures of postnatal day 7 (P7) rat cerebellum (Ghoumari et al., 2003; Table 1). This developmental stage corresponds to a period of intense myelination and also of increased local progesterone synthesis in the cerebellum (Notterpek et al., 1993; Ukena et al., 1999). Adding 10-50 $\mu \mathrm{M}$ of progesterone to the culture medium for 7 days accelerated the process of myelin formation, evaluated by analyzing MBP immunostaining. The micromolar concentrations of progesterone used in this study may seem very elevated, but in this culture system, only part the hormone penetrates the $350 \mu \mathrm{M}$ thick cerebellar slices, which are cultured on top of a microporous membrane and not submerged by the medium (Ghoumari et al., 2003). As for the stimulation of pre-oligodendrocyte proliferation, the promyelinating effect of progesterone involved the classical intracellular PR, as it could be mimicked by the very selective PR agonist R5020 and blocked by the PR antagonist mifepristone. Moreover, progesterone treatment did not stimulate myelination in cerebellar slices sampled from PR knockout mice (Figure 4A). However, this study also provided evidence for an additional involvement of $\mathrm{GABA}_{\mathrm{A}}$ receptor modulation by allopregnanolone: progesterone was metabolized to allopregnanolone in the cerebellar slices, and preventing its formation with the $5 \alpha$-reductase inhibitor L685-273 or inhibiting $\mathrm{GABA}_{\mathrm{A}}$ receptors with bicuculline decreased the promyelinating efficacy of progesterone (Ghoumari et al., 2003). Nevertheless, PR play a key role, as no promyelinating effects of progesterone were observed in PR knockout mice.

The effects of progesterone on myelin repair can also be tested in organotypic cultures of cerebellar slices. As already mentioned, it is always necessary to verify whether signaling mechanisms involved in the regulation of myelin sheath formation during development become again operational during the remyelination of axons after a demyelinating insult. Demyelination can be induced in organotypic slice cultures of the rat and mouse cerebellum by exposing them to lysolecithin (lysophosphatidylcholine, LPC). This experimental system is useful to test the remyelinating efficacy molecules and to analyze underlying signaling mechanisms (Birgbauer et al.,

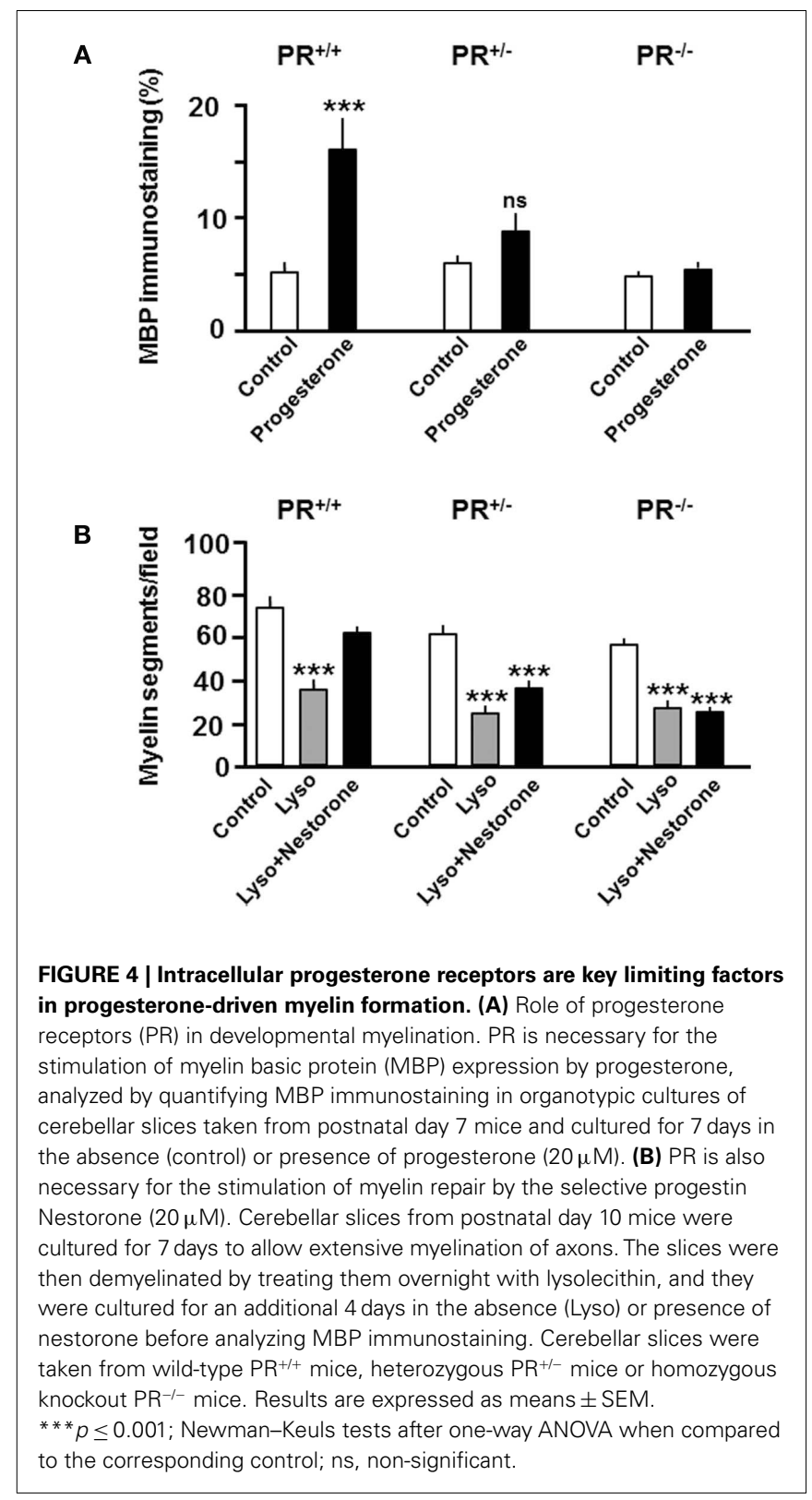

2004; Mi et al., 2009; Miron et al., 2010). To determine whether progesterone also promotes the remyelination of axons, cerebellar slices taken from postnatal day 10 (P10) rats were cultured for 7 days in vitro to allow axons to become myelinated. They were then treated overnight with lysolecithin to induce the demyelination of axons. Four days after lysolecithin-induced demyelination, immunostaining for the myelin marker MBP still appeared sparse when slices were cultured in medium without the addition of progestins. However, in slices cultured for 4 days in the presence of progesterone, there was a marked increase in MBP immunoreactive processes (Hussain et al., 2011). Similarly, when cerebellar slices were exposed to the potent fourth-generation progestin Nestorone, designed to selectively target intracellular PR, dense networks of well-organized myelinated fibers were observed. In contrast, another progestin used in contraception and hormone 
replacement therapy (HRT), the 17-OH progesterone derivative MPA had no significant effect on the formation of new myelin sheaths. This study also revealed that progestins promote the formation of new myelin sheaths via pleiotropic influences on the proliferation, migration, and differentiation of OPC (Hussain et al., 2011).

As for the effect of progesterone on developmental myelination, remyelination by Nestorone involved PR, as it was observed in wild-type $\mathrm{PR}^{+/+}$mice, but not in homozygous knockout $\mathrm{PR}^{-/-}$ mice (Hussain et al., 2011; Figure 4B). Remarkably, the use of transgenic mice allowed the identification of $\mathrm{PR}$ as a limiting factor for the stimulating effects of progesterone on both developmental myelination and remyelination. Indeed, for both processes, progesterone was less efficient in promoting the formation of new myelin sheaths in heterozygous $\mathrm{PR}^{+/-}$when compared to wildtype $\mathrm{PR}^{+/+}$mice (Figure 4; Ghoumari et al., 2003; Hussain et al., 2011). These results provide evidence for PR haploinsufficiency in myelination and myelin repair, as the target tissues of progesterone in $\mathrm{PR}^{+/-}$mice contain about half of the number of $\mathrm{PR}$ binding sites when compared with $\mathrm{PR}^{+/+}$mice (Lydon et al., 1995; Mani et al., 1997). This contrasts with the reproductive functions of $\mathrm{PR}$, for which decreased $\mathrm{PR}$ expression, as observed in $\mathrm{PR}^{+/-}$ mice, does not result in a particular phenotype (Mani et al., 1997). Moreover, it has been suggested that only part of hypothalamic PR needs to be activated for maximal levels of sexual receptivity in female rats (Pfaff and McEwen, 1983).

In vivo, a beneficial influence of progesterone treatment on the replacement of lost myelin was shown in middle-aged male rats ( 9 months old) after toxin-induced demyelination of the caudal cerebellar peduncle (Ibanez et al., 2003b, 2004). The rationale for using males in this study was that they have constant low levels of endogenous progesterone, contrasting with the cyclic variations in females. Older animals were used because aging markedly reduces the endogenous capacity of the brain to repair myelin. This age-related decline in remyelination efficiency has been shown to result from both an impairment of oligodendrocyte progenitor recruitment and differentiation (Sim et al., 2002). Five weeks after creating a focal area of demyelination in cerebellar peduncle by the stereotaxic infusion of ethidium bromide, the extent of spontaneous remyelination was indeed considerably less to that seen in young 10-week-old males. However, treatment of the older males with subcutaneous pellets of progesterone, producing constant elevated levels of the hormone (about $40 \mathrm{nM}$ ), significantly increased the percentage of myelinated axons. As a benchmark, progesterone levels in pregnant rodents reach about $600 \mathrm{nM}$ (Meffre et al., 2007b). Although remyelination in the progesterone-treated animals was not extensive, approximately $20 \%$ of the axons within the lesion, it nevertheless constituted a doubling of the proportion of remyelinated axons when compared to the vehicle-treated control group (Ibanez et al., 2004). This can be considered as a very encouraging result, given that remyelination in older animals has proven remarkably refractory to remyelinating therapeutic approaches (O'Leary et al., 2002).

It is important not to forget that under normal physiological conditions, progesterone does not act alone on target cells, but often in a cooperative manner with estradiol. This goes back to pioneering studies in the early 1980s showing that estradiol treatment increases PR expression in the hypothalamus, and that the time course of the induction of PR by estradiol parallels the time course of the induction of behavioral responsiveness to progesterone (Blaustein and Feder, 1979; Parsons et al., 1980). A recent immunoelectron microscopy study has revealed that the abundant PR labeling in neurites and glial cells in extra-hypothalamic sites such as the hippocampus is also strongly dependent on estrogen priming (Waters et al., 2008). Likewise, in primary cultures of glial cells prepared from neonatal rat brains, PR expression was upregulated by adding estradiol to the culture medium (Jung-Testas et al., 1991).

That estradiol can potentiate the promyelinating effect of progesterone has recently been shown in an experimental model of cuprizone-induced demyelination. Feeding mice the copper chelator cuprizone leads to the apoptosis of oligodendrocyte and the demyelination of axons, which are spared (Matsushima and Morell, 2001). Whereas combined treatment of young male mice with estradiol and progesterone counteracted the loss of myelin in response to cuprizone intoxication within the corpus callosum, the individual application of each steroid only resulted in a moderate prevention of demyelination (Acs et al., 2009). These observations strongly suggest that progestagens may protect oligodendrocytes and promote myelin repair by acting in concert with estrogens, and they point to an increased efficacy of combined progestagen and estrogen administration for treating demyelinating conditions. Thus, future experimental studies on myelination and remyelination should pay more attention to the combined actions of both hormones. Progesterone and estradiol may directly exert combined effects on oligodendrocytes. Thus, both steroids promoted the differentiation of oligodendrocyte progenitors in culture, but whereas progesterone increased cellular branching, estradiol stimulated myelin sheath formation (Marin-Husstege et al., 2004). In addition, the cooperation between progesterone and estradiol may indirectly exert beneficial influences on myelin repair by regulating energy supply and neuroinflammatory responses via astrocytes (Kipp and Beyer, 2009).

An important experimental disease model of multiple sclerosis, which has allowed the evaluation of many medications, is experimental autoimmune encephalomyelitis (EAE; Lassmann, 2008; Stuve et al., 2010). It can be induced in animals by sensitization to myelin antigens (active EAE) or by the transfer of autoreactive T cells (passive EAE). Whereas the above described models of toxin-induced demyelination are valuable to address treatment effects on myelin repair, EAE models are particularly suitable for studying treatment effects on autoimmune and inflammatory responses to demyelination. Beneficial effects on disease severity in EAE have been mainly studied for the estrogens. These studies were motivated by the idea that the immunomodulatory and anti-inflammatory actions of the estradiol may have a beneficial influence on EAE symptoms (Offner, 2004). When administered prior to EAE induction, estrogens delay the onset of symptoms and reduce disease activity. Their immunoprotective effects involve the $\alpha$ isoform of the estrogen receptor (ER; Liu et al., 2003). The mechanisms underlying these beneficial effects most likely involve a wide range of targets and actions. Thus, estrogens have been shown to inhibit the activity of myelin-reactive $\mathrm{T}$ cells and 
inflammatory responses in the brain (Bebo Jr. et al., 2001). A key role of macrophages and microglia in the modulation of immune responses by estrogens has been demonstrated by cell-specific ER disruption (Calippe et al., 2010). More recently, it was shown that the beneficial effects of ER $\alpha$ ligand treatment on CNS inflammation, axonal loss, and neurological outcomes can be prevented by conditional deletion of $\mathrm{ER} \alpha$ from astrocytes. In contrast, deletion of $E R \alpha$ from neurons had no significant effect, pointing to a key role of ER $\alpha$ signaling in astrocytes (Spence et al., 2011).

In comparison with estradiol, the effects of progesterone in EAE have attracted much less attention. However, various types of immune cells express $\mathrm{PR}$, and during pregnancy, progesterone contributes to the establishment of a protective immune environment by modulating multiple immune responses, including a shift away from the production of Th1 pro-inflammatory to Th2 anti-inflammatory cytokines (De Leon-Nava et al., 2009; SzekeresBartho et al., 2009). Regulation of the Th1/Th2 balance by progesterone may play an important role in multiple sclerosis and may contribute to the improvement of disease symptoms during pregnancy and their post-partum worsening (Confavreux et al., 1998). Treating female mice with subcutaneous implants of progesterone starting 1 week prior to EAE induction attenuated disease severity, and reduced inflammatory responses and demyelination in the spinal cord (Garay et al., 2007). Importantly, progesterone also decreased axonal damage and restored the expression of vital neuronal genes (Garay et al., 2009). Whereas estrogens may need to be administered before the induction of EAE, progesterone treatment initiated as late as 2 weeks after immunization with myelin protein peptide still exerted beneficial effects, suggesting a larger therapeutic window (Yates et al., 2010; Yu et al., 2010). However, not all studies have reported beneficial effects of progestagens on EAE symptoms (Kim et al., 1999; Hoffman et al., 2001). Thus, the synthetic progestin MPA, which in contrast to natural progesterone failed to stimulate myelin formation in cerebellar slice cultures, has been reported to increase the severity of EAE (Arnason and Richman, 1969).

\section{THE SIGNIFICANCE OF PROGESTAGENS IN MULTIPLE SCLEROSIS}

Whereas experimental animal studies point to considerable influences of steroids, and in particular of progesterone and estradiol, on demyelinating diseases such as multiple sclerosis, clinical observations have so far provided insufficient or only indirect evidence. A strong indirect argument in favor of hormonal influences on multiple sclerosis is provided by the observed sex differences in the incidence and course of the disease, and by the pregnancyassociated changes in the relapse rate. Thus, according to a crosssectional study conducted in France, the women-men ratio of multiple sclerosis is 2.6 (Fromont et al., 2010). Intriguingly, the gap between sexes in the incidence of the disease has increased over the last decades (Noonan et al., 2002; Bentzen et al., 2010). The course of multiple sclerosis is noticeably influenced by pregnancy. Thus, the rate of relapses is reduced during the last 3 months of pregnancy, when circulating levels of progesterone and estrogens are highest, but it is markedly increased during the first 3 months post-partum, after a drop in sex steroid levels (Confavreux et al., 1998).
Changes in multiple sclerosis symptoms related to the menstrual cycle or menopause are not sufficiently documented and require further evaluation (El-Etr et al., 2011). Also, little is known about the influence of oral contraceptives or postmenopausal HRT on the course of the disease. Taken together, clinical observations point to a protective effect of hormone treatments, but there is a need for large prospective studies (El-Etr et al., 2011). In 2005, a double-blind and placebo-controlled study, named Popart'mus, has been launched to test the combined efficacy of the synthetic 19-nor-progestatif nomegestrol acetate (Lutenyl), taken orally, and of transdermal estradiol patches, in reducing post-partum relapses in women with multiple sclerosis (Vukusic et al., 2009).

An important role of perturbed neurosteroidogenesis in demyelinating diseases has been suggested by a recent study. The expression of enzymes involved in neurosteroid biosynthesis and levels of neurosteroids were found to be dysregulated in the white matter of patients with multiple sclerosis and in a related mouse EAE disease model. In particular, $3 \alpha-\mathrm{HSD}$ expression and brain allopregnanolone levels were decreased. Importantly, treatment of EAE mice with allopregnanolone improved behavioral deficits and neuropathological changes (Noorbakhsh et al., 2011). At the origin of this discovery was a high-throughput profiling of micro-RNA in white matter of patients with or without multiple sclerosis. The analysis revealed in the multiple sclerosis patients a strong upregulation of three micro-RNAs, specifically involved in the suppression of genes coding for steroidogenic enzymes (Noorbakhsh et al., 2011).

\section{DISCUSSION OF THERAPEUTIC OPTIONS WITH PROGESTERONE AND PROGESTINS}

An important role of progesterone in the generation of new oligodendrocytes and in the replacement of lost myelin opens new therapeutic opportunities for demyelinating diseases. Treatment with a progestin is obviously an option for women with multiple sclerosis, as in the ongoing Popart'mus trial (Vukusic et al., 2009). However, the administration of a progestin, in combination with an androgen, may also be considered in men with multiple sclerosis. Thus, combination of a progestin and an androgen is currently tested for male hormonal contraception. Such combined treatments indeed provide efficient suppression of spermatogenesis, and they are efficacious, reversible, and well tolerated (Wang and Swerdloff, 2010). Thus, the transdermal administration of Nestorone and testosterone has been demonstrated to be safe and effective for the suppression of gonadotropins in men (Mahabadi et al., 2009). In this study, Nestorone was administered as a transdermal gel as it is orally inactive (Kumar et al., 2000).

The identification of $\mathrm{PR}$ as a therapeutic target for promoting myelination and myelin repair suggests new therapeutic benefits for contraceptive progestins, and in particular for fourthgeneration 19-nor-progestatifs, specifically designed to specifically target the intracellular PR (Nestorone, nomegestrol acetate). However, it is important to call here attention to the fact that not all synthetic progestins are the same, and that they belong to different classes with very distinct pharmacological properties and actions (Stanczyk, 2003; Hapgood et al., 2004; Schumacher et al., 2007, 2008). Thus, whereas Nestorone promotes myelin repair and has neuroprotective properties, the progestin MPA is devoid of 
such beneficial effects and can even become harmful for neural cells (Liu et al., 2010; Hussain et al., 2011). Indeed, in contrast to natural progesterone and Nestorone, the synthetic $17-\mathrm{OH}$ progesterone derivative MPA was inefficient in stimulating the formation of new myelin sheaths in organotypic cultures of cerebellar slices (Hussain et al., 2011). Likewise, whereas progesterone has a beneficial influence on EAE, the administration of MPA increased disease severity (Arnason and Richman, 1969).

In addition to progestins currently used for contraceptive purposes and HRT, selective progesterone receptor modulators (SPRM), which display different activities in a tissue-specific manner, deserve more attention, and it has become urgent to study their effects on neural cells (Bouchard et al., 2011).

An important question, then, is whether it is meaningful to focus on the therapeutic promises of synthetic progestins for the treatment of demyelinating diseases, or whether the use of natural (bioidentical) progesterone should be preferred? Progestins are definitely an option, and an obvious advantage of certain synthetic compounds is their great selectivity and efficacy. Thus, due to their high potency, very low doses of some progestins may be sufficient and may be delivered via long-term sustainedrelease delivery systems (Sitruk-Ware et al., 2003). On the other hand, natural progesterone may offer a better benefit/risk ratio for prolonged treatments than synthetic progestins. This is strongly suggested by results of the large French E3N prospective cohort study, showing that in contrast to HRT with progestins, the use of natural micronized progesterone is not associated with an increase in breast cancer or thrombotic risk (Fournier et al., 2008; Canonico et al., 2010).

Natural progesterone, tested in most experimental preclinical studies, may also offer a wider range of benefits than the more selective progestins. Indeed, progesterone exerts multiple beneficial effects on the nervous system, which may not be mimicked all by synthetic compounds. First, some of the effects of progesterone in the nervous system, including its neuroprotective and psychopharmacological actions, are mediated by its neuroactive metabolites, and in particular by allopregnanolone (Griffin et al., 2004; Belelli and Lambert, 2005; Sayeed et al., 2006; Wang et al., 2008). In contrast, synthetic progestins are not converted to allopregnanolone and no information is currently available in the literature concerning their metabolism in the brain or other target tissues (Schumacher et al., 2007). Second, research over the past years has revealed multiple targets of progesterone in the nervous system, ranging from the intracellular PR to the recently cloned membrane PR. Not all the progesterone targets may bind synthetic progestins, initially designed to target the classical PR. For example, a series of progestins which bind with high selectivity and affinity to the intracellular PR do not bind to the human membrane PR $\alpha$ isoform (Thomas et al., 2007). Such considerations may have encouraged the use of natural progesterone in two recent phase II trials aimed to evaluate the efficacy of progesterone as a neuroprotective agent in TBI patients (Wright et al., 2007; Xiao et al., 2008).

There is however a major problem with the use of natural progesterone. Indeed, first-pass metabolism in the digestive tract and liver make supplementing with oral progesterone difficult. One option is the use of micronized progesterone, widely used in Europe, and in particular in France, since 1980. Micronized progesterone is natural progesterone, whose average particle size has been reduced, leading to decreased destruction in the gastrointestinal tract, longer half-life, enhanced bioavailability, and efficacy (Schumacher et al., 2007). Its use is well tolerated, with mild, and transient sedation as a side effect that can be minimized by taking the hormone at bedtime (de Lignieres, 1999). However, even after micronization, a large proportion of orally administered progesterone is metabolized by the liver. Thus, there is much interest for other routes of progesterone administration. In the above mentioned neuroprotective trials, progesterone was administered to TBI patients either intravenously (the Atlanta study: Wright et al., 2007) or by intramuscular injections (the Hangzhou study: Xiao et al., 2008). However, these modes of administration are only suitable for acute treatments, and they are difficult to implement in emergency cases. An alternative option for the longer-term treatment of patients with demyelinating diseases is the delivery of progesterone by transdermal or vaginal gels, allowing the hormone to reach its target tissues prior to its metabolism by the liver.

Nasal administration of natural progesterone has received attention as an alternative to specifically target the brain (Costantino et al., 2007). The intranasal route of administration could offer the possibility of achieving the desired brain concentration of progesterone required for myelin repair and neuroprotection, and could offer interesting perspectives both for the efficient acute and long-term use of natural progesterone (Ducharme et al., 2010). Thus, intranasally administered progesterone has been shown to rapidly enhance dopamine levels within specific brain regions (de Souza Silva et al., 2008).

Although most of the pleiotropic effects of progesterone in the nervous system have been reported to be beneficial, there may be a few particular pathological conditions for which progesterone may exert deleterious effects. This is the case for the hereditary neuropathy CMT1A, where progesterone further increases expression of the mutated disease gene PMP22 (Sereda et al., 2003). For this disease, treatment with a PR antagonist or with a SPRM is a therapeutic option.

Progesterone present in the brain is either derived from the steroidogenic endocrine glands or form local synthesis. From this concept derives another therapeutic option for treating degenerative diseases and lesions of the nervous system: stimulating the synthesis of endogenous progesterone and its metabolites in the brain. In this regard, TSPO ligands offer new therapeutic promises (Papadopoulos et al., 2006; Papadopoulos and Lecanu, 2009; Rupprecht et al., 2010). It has indeed been proposed that TSPO ligands may be valuable in the treatment of neurological and psychiatric disorders (Rupprecht et al., 2010). Experimental animal studies have revealed that TSPO expression is upregulated in EAE and after cuprizone-induced demyelination. Interestingly, TSPO levels remains elevated during the period of myelin repair, suggesting a role of the protein the remyelination of axons (Agnello et al., 2000; Chen et al., 2004). Moreover, increased TSPO expression in astrocytes was associated with increased brain levels of progesterone in dysmyelinating mouse mutants (Le Goascogne et al., 2000).

In conclusion, multiple therapeutic approaches remain to be further explored for promoting myelin repair with progestagens 
in demyelinating diseases or after injury. The administration of synthetic progestins and natural progesterone are both interesting options. An important question is their mode of administration. Nasal application, easy to implement for efficient delivery of progesterone into the brain, deserves particular attention. Because natural progesterone is converted in the brain to neuroactive

\section{REFERENCES}

Acs, P., Kipp, M., Norkute, A., Johann, S., Clarner, T., Braun, A., Berente, Z., Komoly, S., and Beyer, C. (2009). 17Beta-estradiol and progesterone prevent cuprizone provoked demyelination of corpus callosum in male mice. Glia 57, 807-814.

Agis-Balboa, R. C., Pinna, G., Zhubi, A., Maloku, E., Veldic, M., Costa, E., and Guidotti, A. (2006). Characterization of brain neurons that express enzymes mediating neurosteroid biosynthesis. Proc. Natl. Acad. Sci. U.S.A. 103, 14602-14607.

Agnello, D., Carvelli, L., Muzio, V., Villa, P., Bottazzi, B., Polentarutti, N., Mennini, T., Mantovani, A., and Ghezzi, P. (2000). Increased peripheral benzodiazepine binding sites and pentraxin 3 expression in the spinal cord during EAE: relation to inflammatory cytokines and modulation by dexamethasone and rolipram. J. Neuroimmunol. 109, 105-111.

Akwa, Y., Schumacher, M., Jung-Testas, I., and Baulieu, E. E. (1993). Neurosteroids in rat sciatic nerves and Schwann cells. C. R. Acad. Sci. III Vie 316, 410-414.

Arensburg, J., Payne, A. H., and Orly, J. (1999). Expression of steroidogenic genes in maternal and extraembryonic cells during early pregnancy in mice. Endocrinology 140, 5220-5232.

Arnason, B. G., and Richman, D. P. (1969). Effect of oral contraceptives on experimental demyelinating disease. Arch. Neurol. 21, 103-108.

Azevedo, F. A., Carvalho, L. R., Grinberg, L. T., Farfel, J. M., Ferretti, R. E., Leite, R. E., Jacob, F. W., Lent, R., and Herculano-Houzel, S. (2009). Equal numbers of neuronal and nonneuronal cells make the human brain an isometrically scaled-up primate brain. J. Comp. Neurol. 513, 532-541.

Back, S. A., Han, B. H., Luo, N. L., Chricton, C. A., Xanthoudakis, S., Tam, J., Arvin, K. L., and Holtzman, D. M. (2002). Selective vulnerability of late oligodendrocyte progenitors to hypoxia-ischemia. J. Neurosci. 22, 455-463.

Backstrom, T., Wahlstrom, G., Wahlstrom, K., Zhu, D., and Wang, M. D. (2005). Isoallopregnanolone; an antagonist to the anaesthetic effect of allopregnanolone in male rats. Eur. J. Pharmacol. 512, 15-21.

Baulieu, E. E. (1997). Neurosteroids: of the nervous system, by the nervous system, for the nervous system. Recent Prog. Horm. Res. 52, 1-32.

Baulieu, E. E., Robel, P., and Schumacher, M. (2001). Neurosteroids: beginning of the story. Int. Rev. Neurobiol. 46, 1-32.

Baumann, N., and Pham-Dinh, D. (2001). Biology of oligodendrocyte and myelin in the mammalian central nervous system. Physiol. Rev. 81, 871-927.

Bebo, B. F. Jr., Fyfe-Johnson, A., Adlard, K., Beam, A. G., Vandenbark, A. A., and Offner, H. (2001). Low-dose estrogen therapy ameliorates experimental autoimmune encephalomyelitis in two different inbred mouse strains. J. Immunol. 166, 2080-2089.

Belelli, D., and Herd, M. B. (2003). The contraceptive agent Provera enhances GABA(A) receptor-mediated inhibitory neurotransmission in the rat hippocampus: evidence for endoge10013-10020.

Belelli, D., and Lambert, J. J. (2005). Neurosteroids: endogenous regulators of the GABA(A) receptor. Nat. Rev. Neurosci. 6, 565-575.

Belyaeva, O. V., Chetyrkin, S. V., Clark, A. L., Kostereva, N. V., SantaCruz, K. S., Chronwall, B. M., and Kedishvili, N. Y. (2007). Role of microsomal retinol/sterol dehydrogenase-like short-chain dehydrogenases/reductases in the oxidation and epimerization of 3alpha-hydroxysteroids in human tissues. Endocrinology 148, 2148-2156.

Bentzen, J., Flachs, E. M., Stenager, E., Bronnum-Hansen, H., and KochHenriksen, N. (2010). Prevalence of multiple sclerosis in Denmark 1950-2005. Mult. Scler. 16, 520-525.

Beyenburg, S., Stoffel-Wagner, B., Watzka, M., Blumcke, I., Bauer, J., Schramm, J., Bidlingmaier, F., and Elger, C. E. (1999). Expression of cytochrome P450scc mRNA in the hippocampus of patients with temporal lobe epilepsy. Neuroreport 10, 3067-3070. nous neurosteroids? J. Neurosci. 23,

metabolites, and because the hormone targets multiple signaling mechanisms, its future use for the treatment of demyelinating diseases, and other neurological disorders should be considered. Stimulating the production of endogenous neuroprogesterone in the nervous system with TSPO ligands offers new perspectives for remyelinating and neuroprotective interventions.

Birgbauer, E., Rao, T. S., and Webb, M. (2004). Lysolecithin induces demyelination in vitro in a cerebellar slice culture system. J. Neurosci. Res. 78, 157-166.

Bitran, D., Foley, M., Audette, D., Leslie, N., and Frye, C. A. (2000). Activation of peripheral mitochondrial benzodiazepine receptors in the hippocampus stimulates allopregnanolone synthesis and produces anxiolytic-like effects in the rat. Psychopharmacology (Berl.) 151, 64-71.

Björkhem, I., and Meaney, S. (2004). Brain cholesterol: long secret life behind a barrier. Arterioscler. Thromb. Vasc. Biol. 24, 806-815.

Blaustein, J. D., and Feder, H. H. (1979). Cytoplasmic progestin-receptors in guinea pig brain: characteristics and relationship to the induction of sexual behavior. Brain Res. 169 , 481-497.

Bolin, L. M., and Shooter, E. M. (1993). Neurons regulate Schwann cell genes by diffusible molecules. J. Cell Biol. $123,237-243$

Bouchard, P., Chabbert-Buffet, N., and Fauser, B. C. (2011). Selective progesterone receptor modulators in reproductive medicine: pharmacology, clinical efficacy and safety. Fertil. Steril. 96, 1175-1189.

Brinkmann, B. G., Agarwal, A., Sereda, M. W., Garratt, A. N., Muller, T., Wende, H., Stassart, R. M., Nawaz, S., Humml, C., Velanac, V. Radyushkin, K., Goebbels, S., Fischer, T. M., Franklin, R. J., Lai, C., Ehrenreich, H., Birchmeier, C., Schwab, M. H., and Nave, K. A. (2008). Neuregulin-1/ErbB signaling serves distinct functions in myelination of the peripheral and central nervous system. Neuron 59, 581-595.

Calippe, B., Douin-Echinard, V., Delpy, L., Laffargue, M., Lelu, K., Krust, A., Pipy, B., Bayard, F., Arnal, J. F., Guery, J. C., and Gourdy, P. (2010). 17\{Beta\}-estradiol promotes TLR4triggered proinflammatory mediator production through direct estrogen receptor $\{$ alpha $\}$ signaling in macrophages in vivo. J. Immunol. 185, 1169-1176.

Canonico, M., Fournier, A., Carcaillon, L., Olie, V., Plu-Bureau Oger, E., Mesrine, S., Boutron-Ruault, M.
C., Clavel-Chapelon, F., and Scarabin, P. Y. (2010). Postmenopausal hormone therapy and risk of idiopathic venous thromboembolism: results from the E3N cohort study. Arterioscler. Thromb. Vasc. Biol. 30, 340-345.

Celotti, F., Melcangi, R. C., and Martini, L. (1992). The 5 alpha-reductase in the brain: molecular aspects and relation to brain function. Front. Neuroendocrinol. 13, 163-215.

Chan, J. R., Phillips, L. J., and Glaser, M. (1998). Glucocorticoids and progestins signal the initiation and enhance the rate of myelin formation. Proc. Natl. Acad. Sci. U.S.A. 95, 10459-10464.

Chan, J. R., Rodriguez-Waitkus, P. M., Ng, B. K., Liang, P., and Glaser, M. (2000). Progesterone synthesized by Schwann cells during myelin formation regulates neuronal gene expression. Mol. Biol. Cell 11, 2283-2295.

Chan, J. R., Watkins, T. A., Cosgaya, J. M., Zhang, C., Chen, L., Reichardt, L. F., Shooter, E. M., and Barres, B. A (2004). NGF controls axonal receptivity to myelination by Schwann cells or oligodendrocytes. Neuron 43 , 183-191.

Chang, A., Tourtellotte, W. W., Rudick, R., and Trapp, B. D. (2002). Premyelinating oligodendrocytes in chronic lesions of multiple sclerosis. N. Engl. J. Med. 346, 165-173.

Chen, M. K., Baidoo, K., Verina, T., and Guilarte, T. R. (2004). Peripheral benzodiazepine receptor imag ing in CNS demyelination: functional implications of anatomical and cellular localization. Brain 127, 1379-1392.

Chen, Z. L., Yu, W. M., and Strickland, S. (2007). Peripheral regeneration. Annu. Rev. Neurosci. 30, 209-233.

Cherradi, N., Chambaz, E. M., and Defaye, G. (1995). Organization of 3 beta-hydroxysteroid dehydrogenase/isomerase and cytochrome P450scc into a catalytically active molecular complex in bovine adrenocortical mitochondria. J. Steroid Biochem. Mol. Biol. 55, 507-514.

Chesik, D., and De, K. J. (2010). Progesterone and dexamethasone differentially regulate the IGF-system in glial cells. Neurosci. Lett. 468, 178-182. 
Chetyrkin, S. V., Belyaeva, O. V., Gough, W. H., and Kedishvili, N. Y. (2001). Characterization of a novel type of human microsomal 3alpha -hydroxysteroid dehydrogenase: unique tissue distribution and catalytic properties. J. Biol. Chem. 276, 22278-22286.

Chrast, R., Saher, G., Nave, K. A., and Verheijen, M. H. (2011). Lipid metabolism in myelinating glial cells: lessons from human inherited disorders and mouse models. J. Lipid Res. 52, 419-434.

Coirini, H., Gouezou, M., Delespierre, B., Liere, P., Pianos, A., Eychenne, B., Schumacher, M., and Guennoun, R. (2003a). Characterization and regulation of the 3beta-hydroxysteroid dehydrogenase isomerase enzyme in the rat sciatic nerve. J. Neurochem. 84, 119-126.

Coirini, H., Gouezou, M., Delespierre, B., Schumacher, M., and Guennoun, R. (2003b). 3 beta-hydroxysteroid dehydrogenase isomerase (3betaHSD) activity in the rat sciatic nerve: kinetic analysis and regulation by steroids. J. Steroid Biochem. Mol. Biol. 85, 89-94.

Coirini, H., Gouezou, M., Liere, P., Delespierre, B., Pianos, A., Eychenne, B., Schumacher, M., and Guennoun, R. (2002). 3 Beta-hydroxysteroid dehydrogenase expression in rat spinal cord. Neuroscience 113, 883-891.

Coleman, M. P., and Freeman, M. R. (2010). Wallerian degeneration, wld(s), and nmnat. Annu. Rev. Neurosci. 33, 245-267.

Compagnone, N. A., Bulfone, A., Rubenstein, J. L., and Mellon, S. H. (1995). Expression of the steroidogenic enzyme P450scc in the central and peripheral nervous systems during rodent embryogenesis. Endocrinology 136, 2689-2696.

Compagnone, N. A., and Mellon, S. H. (2000). Neurosteroids: biosynthesis and function of these novel neuromodulators. Front. Neuroendocrinol. 21, 1-56.

Confavreux, C., Hutchinson, M., Hours, M. M., Cortinovis-Tourniaire, P., and Moreau, T. (1998). Rate of pregnancy-related relapse in multiple sclerosis. Pregnancy in Multiple Sclerosis Group. N. Engl. J. Med.339, 285-291.

Costantino, H. R., Illum, L., Brandt, G., Johnson, P. H., and Quay, S. C. (2007). Intranasal delivery: physicochemical and therapeutic aspects. Int. J. Pharm. 337, $1-24$.

Daniel, A. R., Knutson, T. P., and Lange, C. A. (2009). Signaling inputs to progesterone receptor gene regulation and promoter selectivity. $\mathrm{Mol}$. Cell. Endocrinol. 308, 47-52.

Dawson, M. R., Polito, A., Levine, J. M., and Reynolds, R. (2003). NG2expressing glial progenitor cells: an abundant and widespread population of cycling cells in the adult rat CNS. Mol. Cell. Neurosci. 24, 476-488.

De Leon-Nava, M. A., Nava, K., Soldevila, G., Lopez-Griego, L., ChavezRios, J. R., Vargas-Villavicencio, J. A., and Morales-Montor, J. (2009). Immune sexual dimorphism: effect of gonadal steroids on the expression of cytokines, sex steroid receptors, and lymphocyte proliferation. J. Steroid Biochem. Mol. Biol. 113, 57-64.

de Lignieres, B. (1999). Oral micronized progesterone. Clin. Ther. 21, 41-60.

De Nicola, A. F., Labombarda, F., Deniselle, M. C., Gonzalez, S. L., Garay, L., Meyer, M., Gargiulo, G., Guennoun, R., and Schumacher, M. (2009). Progesterone neuroprotection in traumatic CNS injury and motoneuron degeneration. Front. Neuroendocrinol. 30, 173-187.

de Souza Silva, M. A., Topic, B., Huston, J. P., and Mattern, C. (2008). Intranasal administration of progesterone increases dopaminergic activity in amygdala and neostriatum of male rats. Neuroscience 157, 196-203.

Deblois, G., and Giguere, V. (2008). Nuclear receptor location analyses in mammalian genomes: from gene regulation to regulatory networks. Mol. Endocrinol. 22, 1999-2011.

Désarnaud, F., Bidichandani, S., Patel, P. I., Baulieu, E. E., and Schumacher, M. (2000). Glucocorticosteroids stimulate the activity of the promoters of peripheral myelin protein-22 and protein zero genes in Schwann cells. Brain Res. 865, 12-16.

Désarnaud, F., Do, T., Brown, A. M., Lemke, G., Suter, U., Baulieu, E. E., and Schumacher, M. (1998). Progesterone stimulates the activity of the promoters of peripheral myelin protein-22 and protein zero genes in Schwann cells. J. Neurochem. 71, 1765-1768.

Do Rego, J. L., Seong, J. Y., Burel, D., Leprince, J., Luu-The, V., Tsutsui, K., Tonon, M. C., Pelletier, G., and Vaudry, H. (2009). Neurosteroid biosynthesis: enzymatic pathways and neuroendocrine regulation by neurotransmitters and neuropeptides. Front. Neuroendocrinol. 30, 259-301.

Ducharme, N., Banks, W. A., Morley, J. E., Robinson, S. M., Niehoff,
M. L., and Mattern, C. (2010). Brain distribution and behavioral effects of progesterone and pregnenolone after intranasal or intravenous administration. Eur. J. Phar macol. 641, 128-134.

Eichberg, J. (2002). Myelin P0: new knowledge and new roles. Neurochem. Res. 27, 1331-1340.

Eldar-Geva, T., Margalioth, E. J., Brooks, B., Algur, N., Zylber-Haran, E., and Diamant, Y. Z. (1998). The origin of serum progesterone during the follicular phase of menotropinstimulated cycles. Hum. Reprod. 13, 9-14.

El-Etr, M., Ghoumari, A., Sitruk-Ware, R., and Schumacher, M. (2011). Hormonal influences in multiple sclerosis: new therapeutic benefits for steroids. Maturitas 68, 47-51.

Fajer, A. B., Holzbauer, M., and Newport, H. M. (1971). The contribution of the adrenal gland to the total amount of progesterone produced in the female rat. J. Physiol. (Lond.) 214, 115-126.

Fancy, S. P., Chan, J. R., Baranzini, S. E., Franklin, R. J., and Rowitch, D. H. (2011). Myelin regeneration: a recapitulation of development? Annu. Rev. Neurosci. 34, 21-43.

Fawcett, J. W., and Keynes, R. J. (1990). Peripheral nerve regeneration. Annu. Rev. Neurosci. 13, 43-60.

Fournier, A., Berrino, F., and ClavelChapelon, F. (2008). Unequal risks for breast cancer associated with different hormone replacement therapies: results from the E3N cohort study. Breast Cancer Res. Treat. 107, 103-111.

Franklin, R. J., and FFrench-Constant, C. (2008). Remyelination in the CNS: from biology to therapy. Nat. Rev. Neurosci. 9, 839-855.

Franklin, R. J., and Kotter, M. R. (2008). The biology of CNS remyelination: the key to therapeutic advances. J. Neurol. 255(Suppl. 1), 19-25.

Fromont, A., Binquet, C., Sauleau, E. A., Fournel, I., Bellisario, A., Adnet, J., Weill, A., Vukusic, S., Confavreux, C., Debouverie, M., Clerc, L., BonithonKopp, C., and Moreau, T. (2010). Geographic variations of multiple sclerosis in France. Brain 133, 1889-1899.

Gago, N., Akwa, Y., Sananes, N., Guennoun, R., Baulieu, E. E., El, E., and Schumacher, M. (2001). Progesterone and the oligodendroglial lineage: stage-dependent biosynthesis and metabolism. Glia 36, 295-308.

Gago, N., Avellana, A., Evercooren, A. B., and Schumacher, M. (2003). Control of cell survival and proliferation of postnatal PSA-NCAM $(+)$ progenitors. Mol. Cell. Neurosci. 22, 162-178.

Gago, N., El-Etr, M., Sananes, N., Cadepond, F., Samuel, D., vellana-Adalid, V., Baron-Van, E. A., and Schumacher, M. (2004). 3alpha,5alpha-Tetrahydro progesterone (allopregnanolone) and gamma-aminobutyric acid: autocrine/paracrine interactions in the control of neonatal PSANCAM+ progenitor proliferation. $J$ Neurosci. Res. 78, 770-783.

Garay, L., Deniselle, M. C., Lima, A., Roig, P., and De Nicola, A. F. (2007). Effects of progesterone in the spinal cord of a mouse model of multiple sclerosis. J. Steroid Biochem. Mol. Biol. 107, 228-237.

Garay, L., Deniselle, M. C., Meyer, M., Costa, J. J., Lima, A., Roig, P., and De Nicola, A. F. (2009). Protective effects of progesterone administration on axonal pathology in mice with experimental autoimmune encephalomyelitis. Brain Res. 1283, 177-185.

Garcia-Segura, L. M., Azcoitia, I., and Doncarlos, L. L. (2001). Neuroprotection by estradiol. Prog. Neurobiol. 63, 29-60.

Geisert, E. E. Jr., Williams, R. W., Geisert, G. R., Fan, L., Asbury, A. M., Maecker, H. T., Deng, J., and Levy, S. (2002). Increased brain size and glial cell number in CD81-null mice. J. Comp. Neurol. 453, 22-32.

Ghoumari, A. M., Baulieu, E. E., and Schumacher, M. (2005). Progesterone increases oligodendroglial cell proliferation in rat cerebellar slice cultures. Neuroscience 135, 47-58.

Ghoumari, A. M., Ibanez, C., El-Etr, M., Leclerc, P., Eychenne, B., Malley, B. W., Baulieu, E. E., and Schumacher, M. (2003). Progesterone and its metabolites increase myelin basic protein expression in organotypic slice cultures of rat cerebellum. J. Neurochem. 86, 848-859.

Giambonini-Brugnoli, G., Buchstaller, J., Sommer, L., Suter, U., and Mantei, N. (2005). Distinct disease mechanisms in peripheral neuropathies due to altered peripheral myelin protein 22 gene dosage or a Pmp22 point mutation. Neurobiol. Dis. 18, 656-668.

Gould, E., Woolley, C. S., Frankfurt, M., and McEwen, B. S. (1990). Gonadal steroids regulate dendritic spine density in hippocampal pyramidal cells in adulthood. J. Neurosci. 10, 1286-1291.

Griffin, L. D., Gong, W., Verot, L., and Mellon, S. H. (2004). Niemann-Pick type $\mathrm{C}$ disease involves disrupted 
neurosteroidogenesis and responds to allopregnanolone. Nat. Med. 10, 704-711.

Grobin, A. C., Gizerian, S., Lieberman, J. A., and Morrow, A. L. (2006). Perinatal allopregnanolone influences prefrontal cortex structure, connectivity and behavior in adult rats. Neuroscience 138, 809-819.

Grobin, A. C., Heenan, E. J., Lieberman, J. A., and Morrow, A. L. (2003). Perinatal neurosteroid levels influence GABAergic interneuron localization in adult rat prefrontal cortex. J. Neurosci. 23, 1832-1839.

Groyer, G., Eychenne, B., Girard, C., Rajkowski, K., Schumacher, M., and Cadepond, F. (2006). Expression and functional state of the corticosteroid receptors and 11betahydroxysteroid dehydrogenase type 2 in Schwann cells. Endocrinology 147, 4339-4350.

Guennoun, R., Fiddes, R. J., Gouézou, M., Lombès, M., and Baulieu, E. E. (1995). A key enzyme in the biosynthesis of neurosteroids, 3 beta-hydroxysteroid dehydrogenase/delta 5-delta 4-isomerase (3 beta-HSD), is expressed in rat brain. Brain Res. Mol. Brain Res. 30, 287-300.

Guennoun, R., Schumacher, M., Robert, F., Delespierre, B., Gouézou, M., Eychenne, B., Akwa, Y., Robel, P., and Baulieu, E. E. (1997). Neurosteroids: expression of functional 3beta-hydroxysteroid dehydrogenase by rat sensory neurons and Schwann cells. Eur. J. Neurosci. 9, 2236-2247.

Gutai, J. P., Meyer, W. J., Kowarski, A. A., and Migeon, C. J. (1977). Twenty-four hour integrated concentrations of progesterone, 17hydroxyprogesterone and cortisol in normal male subjects. J. Clin. Endocrinol. Metab. 44, 116-120.

Hapgood, J. P., Koubovec, D., Louw, A., and Africander, D. (2004). Not all progestins are the same: implications for usage. Trends Pharmacol. Sci. 25, 554-557.

Harauz, G., Ladizhansky, V., and Boggs, J. M. (2009). Structural polymorphism and multifunctionality of myelin basic protein. Biochemistry 48, 8094-8104.

Hartline, D. K., and Colman, D. R. (2007). Rapid conduction and the evolution of giant axons and myelinated fibers. Curr. Biol. 17, R29-R35.

Higashi, T., Sakajiri, K., and Shimada, K. (2004). Analysis of C3 epimerization in (24R)-24,25dihydroxyvitamin D3 catalyzed by hydroxysteroid dehydrogenase. J. Pharm. Biomed. Anal. 36, 429-436.
Hirst, J. J., Palliser, H. K., Yates, D. M., Yawno, T., and Walker, D. W. (2008). Neurosteroids in the fetus and neonate: potential protective role in compromised pregnancies. Neurochem. Int. 52, 602-610.

Hoffman, G. E., Le, W. W., Murphy, A. Z., and Koski, C. L. (2001). Divergent effects of ovarian steroids on neuronal survival during experimental allergic encephalitis in Lewis rats. Exp. Neurol. 171, 272-284.

Huang, J. K., and Franklin, R. J. (2011). Regenerative medicine in multiple sclerosis: identifying pharmacological targets of adult neural stem cell differentiation. Neurochem. Int. 59, 329-332.

Hussain, R., El-Etr, M., Gaci, O., Rakotomamonjy, J., Macklin, W. B., Kumar, N., Sitruk-Ware, R., Schumacher, M., and Ghoumari, A. M. (2011). Progesterone and nestorone facilitate axon remyelination: a role for progesterone receptors. Endocrinology 152, 3820-3831.

Ibanez, C., Guennoun, R., Liere, P., Eychenne, B., Pianos, A., El Etr, M., Baulieu, E. E., and Schumacher, M. (2003a). Developmental expression of genes involved in neurosteroidogenesis: 3beta-hydroxysteroid dehydrogenase/delta5-delta4 isomerase in the rat brain. Endocrinology 144, 2902-2911.

Ibanez, C., Shields, S. A., El Etr, M., Leonelli, E., Magnaghi, V., Li, W. W., Sim, F. J., Baulieu, E. E., Melcangi, R. C., Schumacher, M., and Franklin, R. J. (2003b). Steroids and the reversal of age-associated changes in myelination and remyelination. Prog. Neurobiol. 71, 49-56.

Ibanez, C., Shields, S. A., El-Etr, M., Baulieu, E. E., Schumacher, M., and Franklin, R. J. M. (2004). Systemic progesterone administration results in a partial reversal of the age-associated decline in CNS remyelination following toxininduced demyelination in male rats. Neuropathol. Appl. Neurobiol. 30, 80-89.

Inoue, T., Akahira, J., Suzuki, T., Darnel, A. D., Kaneko, C., Takahashi, K., Hatori, M., Shirane, R., Kumabe, T., Kurokawa, Y., Satomi, S., and Sasano, H. (2002). Progesterone production and actions in the human central nervous system and neurogenic tumors. J. Clin. Endocrinol. Metab. 87, 5325-5331.

Inquimbert, P., Rodeau, J. L., and Schlichter, R. (2008). Regional differences in the decay kinetics of $\mathrm{GABA}(\mathrm{A})$ receptor-mediated miniature IPSCs in the dorsal horn of the rat spinal cord are determined by mitochondrial transport of cholesterol. J. Neurosci. 28, 3427-3437.

Ishibashi, T., Dakin, K. A., Stevens, B. Lee, P. R., Kozlov, S. V., Stewart, C. L. and Fields, R. D. (2006). Astrocytes promote myelination in response to electrical impulses. Neuron 49 , 823-832.

Ishikura, S., Usami, N., Nakajima, S., Kameyama, A., Shiraishi, H., Carbone, V., El-Kabbani, O., and Hara, A. (2004). Characterization of two isoforms of mouse 3(17)alphahydroxysteroid dehydrogenases of the aldo-keto reductase family. Biol. Pharm. Bull. 27, 1939-1945.

Jung-Testas, I., Hu, Z. Y., Baulieu, E. E., and Robel, P. (1989). Neurosteroids: biosynthesis of pregnenolone and progesterone in primary cultures of rat glial cells. Endocrinology 125 , 2083-2091.

Jung-Testas, I., Renoir, J. M., Gasc, J. M. and Baulieu, E. E. (1991). Estrogeninducible progesterone receptor in primary cultures of rat glial cells. Exp. Cell Res. 193, 12-19.

Jung-Testas, I., Schumacher, M., Robel, P., and Baulieu, E. E. (1996). Demonstration of progesterone receptors in rat Schwann cells. J. Steroid Biochem. Mol. Biol. 58, 77-82.

Jurevics, H., Bouldin, T. W., Toews, A. D., and Morell, P. (1998). Regenerating sciatic nerve does not utilize circulating cholesterol. Neurochem. Res. 23, 401-406.

Jurevics, H., and Morell, P. (1995). Cholesterol for synthesis of myelin is made locally, not imported into brain. J. Neurochem. 64, 895-901.

Karim, S. A., Barrie, J. A., Mcculloch, M. C., Montague, P., Edgar, J. M., Kirkham, D., Anderson, T. J., Nave, K. A., Griffiths, I. R., and McLaughlin, M. (2007). PLP overexpression perturbs myelin protein composition and myelination in a mouse model of PelizaeusMerzbacher disease. Glia 55, 341-351.

Keller, A. F., Breton, J. D., Schlichter, R., and Poisbeau, P. (2004). Production of 5alpha-reduced neurosteroids is developmentally regulated and shapes GABA(A) miniature IPSCs in lamina II of the spinal cord. J. Neurosci. 24, 907-915.

Kim, S., Liva, S. M., Dalal, M. A., Verity, M. A., and Voskuhl, R. R. (1999). Estriol ameliorates autoimmune demyelinating disease: implications for multiple sclerosis. $\mathrm{Neu}$ rology 52, 1230-1238.

Kipp, M., and Beyer, C. (2009). Impact of sex steroids on neuroinflammatory processes and experimental multiple sclerosis. Front. Neuroendocrinol. 30, 188-200.

Klieber, M. A., Underhill, C., Hammond, G. L., and Muller, Y. A. (2007). Corticosteroid-binding globulin, a structural basis for steroid transport and proteinase-triggered release. $J$. Biol. Chem. 282, 29594-29603.

Koenig, H. L., Schumacher, M., Ferzaz, B., Do Thi, A. N., Ressouches, A., Guennoun, R., Jung-Testas, I., Robel, P., Akwa, Y., and Baulieu, E. E. (1995). Progesterone synthesis and myelin formation by Schwann cells. Science 268, 1500-1503.

Korneyev, A., Pan, B. S., Polo, A., Romeo, E., Guidotti, A., and Costa, E. (1993). Stimulation of brain pregnenolone synthesis by mitochondrial diazepam binding inhibitor receptor ligands in vivo. $\mathrm{J}$. Neurochem. 61, 1515-1524.

Kuhlmann, T., Miron, V., Cuo, Q., Wegner, C., Antel, J., and Bruck, W. (2008). Differentiation block of oligodendroglial progenitor cells as a cause for remyelination failure in chronic multiple sclerosis. Brain 131 , 1749-1758.

Kumar, N., Koide, S. S., Tsong, Y., and Sundaram, K. (2000). Nestorone: a progestin with a unique pharmacological profile. Steroids 65, 629-636.

Labombarda, F., Gonzalez, S., Lima, A., Roig, P., Guennoun, R., Schumacher, M., and De Nicola, A. F. (2011). Progesterone attenuates astro- and microgliosis and enhances oligodendrocyte differentiation following spinal cord injury. Exp. Neurol. 231, 135-146.

Labombarda, F., Gonzalez, S. L., Lima, A., Roig, P., Guennoun, R., Schumacher, M., and De Nicola, A. F (2009). Effects of progesterone on oligodendrocyte progenitors, oligodendrocyte transcription factors and myelin proteins following spinal cord injury. Glia 57, 884-897.

Labombarda, F., Pianos, A., Liere, P. Eychenne, B., Gonzalez, S., Cambourg, A., De Nicola, A. F., Schumacher, M., and Guennoun, R. (2006). Injury elicited increase in spinal cord neurosteroid content analysed by gas chromatography mass spectrometry. Endocrinology 147, 1847-1859.

Lacroix-Fralish, M. L., Tawfik, V. L., Nutile-McMenemy, N., Harris, B. T., and DeLeo, J. A. (2006). Differential regulation of neuregulin 1 expression by progesterone in astrocytes and neurons. Neuron Glia Biol. 2, 227-234.

Lambert, J. J., Cooper, M. A., Simmons, R. D., Weir, C. J., and Belelli, D. 
(2009). Neurosteroids: endogenous allosteric modulators of GABA(A) receptors. Psychoneuroendocrinology 34(Suppl. 1), S48-S58.

Lassmann, H. (2008). Models of multiple sclerosis: new insights into pathophysiology and repair. Curr. Opin. Neurol. 21, 242-247.

Le Goascogne, C., Eychenne, B., Tonon, M. C., Lachapelle, F., Baumann, N., and Robel, P. (2000). Neurosteroid progesterone is up-regulated in the brain of jimpy and shiverer mice. Glia 29, 14-24.

Le Goascogne, C., Gouézou, M., Robel, P., Defaye, G., Chambaz, E., Waterman, M. R., and Baulieu, E. E. (1989). The cholesterol side-chain cleavage complex in human brain white matter. J. Neuroendocrinol. 1, 153-156.

Levine, J. M., Reynolds, R., and Fawcett, J. W. (2001). The oligodendrocyte precursor cell in health and disease. Trends Neurosci. 24, 39-47.

Liere, P., Akwa, Y., Weill-Engerer, S., Eychenne, B., Pianos, A., Robel, P., Sjovall, J., Schumacher, M., and Baulieu, E. E. (2000). Validation of an analytical procedure to measure trace amounts of neurosteroids in brain tissue by gas chromatographymass spectrometry. J. Chromatogr. B Biomed. Sci. Appl. 739, 301-312.

Liu, H. B., Loo, K. K., Palaszynski, K., Ashouri, J., Lubahn, D. B., and Voskuhl, R. R. (2003). Estrogen receptor alpha mediates estrogen's immune protection in autoimmune disease. J. Immunol. 171, 6936-6940.

Liu, L., Zhao, L., She, H., Chen, S., Wang, J. M., Wong, C., McClure, K., SitrukWare, R., and Brinton, R. D. (2010). Clinically relevant progestins regulate neurogenic and neuroprotective responses in vitro and in vivo. Endocrinology 151, 5782-5794.

Luine, V., Park, D., Joh, T., Reis, D., and McEwen, B. (1980). Immunochemical demonstration of increased choline acetyltransferase concentration in rat preoptic area after estradiol administration. Brain Res. 191, 273-277.

Lydon, J. P., DeMayo, F. J., Funk, C. R., Mani, S. K., Hughes, A. R., Montgomery, C. A., Shyamala, G., Conneely, O. M., and O'Malley, B. W. (1995). Mice lacking progesterone receptor exhibit pleiotropic reproductive abnormalities. Genes Dev. 9 , 2266-2278.

Lytle, J. M., and Wrathall, J. R. (2007). Glial cell loss, proliferation and replacement in the contused murine spinal cord. Eur. J. Neurosci. 25, 1711-1724.
Magnaghi, V., Cavarretta, I., Zucchi, I., Susani, L., Rupprecht, R., Hermann, B., Martini, L., and Melcangi, R. C. (1999). Po gene expression is modulated by androgens in the sciatic nerve of adult male rats. Brain Res. Mol. Brain Res. 70, 36-44.

Mahabadi, V., Amory, J. K., Swerdloff, R. S., Bremner, W. J., Page, S. T., Sitruk-Ware, R., Christensen, P. D., Kumar, N., Tsong, Y. Y., Blithe, D., and Wang, C. (2009). Combined transdermal testosterone gel and the progestin nestorone suppresses serum gonadotropins in men. J. Clin. Endocrinol. Metab. 94, 2313-2320.

Majewska, M. D., Harrison, N. L., Schwartz, R. D., Barker, J. L., and Paul, S. M. (1986). Steroid hormone metabolites are barbituratelike modulators of the GABA receptor. Science 232, 1004-1007.

Mani, S. K., Blaustein, J. D., and O’Malley, B. W. (1997). Progesterone receptor function from a behavioral perspective. Horm. Behav. 31, 244-255.

Marin-Husstege, M., Muggironi, M., Raban, D., Skoff, R. P., and CasacciaBonnefil, P. (2004). Oligodendrocyte progenitor proliferation and maturation is differentially regulated by male and female sex steroid hormones. Dev. Neurosci. 26, 245-254.

Matsushima, G. K., and Morell, P. (2001). The neurotoxicant, cuprizone, as a model to study demyelination and remyelination in the central nervous system. Brain Pathol. 11, 107-116.

McEwen, B. S. (2001). Invited review: estrogens effects on the brain: multiple sites and molecular mechanisms. J. Appl. Physiol. 91, 2785-2801.

Meffre, D., Delespierre, B., Gouezou, M., Schumacher, M., Stein, D. G., and Guennoun, R. (2007a). 3beta-Hydroxysteroid dehydrogenase/5-ene-4-ene isomerase mRNA expression in rat brain: effect of pseudopregnancy and traumatic brain injury. J. Steroid Biochem. Mol. Biol. 104, 293-300.

Meffre, D., Pianos, A., Liere, P., Eychenne, B., Cambourg, A., Schumacher, M., Stein, D. G., and Guennoun, R. (2007b). Steroid profiling in brain and plasma of male and pseudopregnant female rats after traumatic brain injury: analysis by gas chromatography/mass spectrometry. Endocrinology 148, 2505-2517.

Melcangi, R. C., Ballabio, M., Cavarretta, I., Gonzalez, L. C., Leonelli,
E., Veiga, S., Martini, L., and Magnaghi, V. (2003). Effects of neuroactive steroids on myelin of peripheral nervous system. J. Steroid Biochem. Mol. Biol. 85, 323-327.

Melcangi, R. C., Cavarretta, I. T., Ballabio, M., Leonelli, E., Schenone, A., Azcoitia, I., Miguel Garcia-Segura, L., and Magnaghi, V. (2005). Peripheral nerves: a target for the action of neuroactive steroids. Brain Res. Rev. 48, 328-338.

Melcangi, R. C., Celotti, F., Ballabio, M. Poletti, A., Castano, P., and Martini, L. (1988). Testosterone $5 \alpha$-reductase activity in the rat brain is highly concentrated in white matter structures and in purified myelin sheaths of axons. J. Steroid Biochem. 31, 173-179.

Melcangi, R. C., Celotti, F., and Martini, L. (1994). Progesterone 5alpha-reduction in neuronal and in different types of glial cell cultures: type 1 and 2 astrocytes and oligodendrocytes. Brain Res. 639, 202-206.

Melcangi, R. C., Magnaghi, V., Cavarretta, I., Zucchi, I., Bovolin, P., D'Urso, D., and Martini, L. (1999). Progesterone derivatives are able to influence peripheral myelin protein 22 and P0 gene expression: possible mechanisms of action. J. Neurosci. Res. 56, 349-357.

Melcangi, R. C., Poletti, A., Cavarretta, I., Celotti, F., Colciago, A., Magnaghi, V., Motta, M., Negri-Cesi, P. and Martini, L. (1998). The 5alphareductase in the central nervous system: expression and modes of control. J. Steroid Biochem. Mol. Biol. 65, 295-299.

Mellon, S. H. (2007). Neurosteroid regulation of central nervous system development. Pharmacol. Ther. 116 107-124.

Mellon, S. H., and Deschepper, C. F. (1993). Neurosteroid biosynthesis: genes for adrenal steroidogenic enzymes are expressed in the brain. Brain Res. 629, 283-292.

Mellon, S. H., and Vaudry, H. (2001). Biosynthesis of neurosteroids and regulation of their synthesis. Int. Rev. Neurobiol. 46, 33-78.

Mensah-Nyagan, A. G., Feuilloley, M., Dupont, E., Do-Rego, J. L., Leboulenger, F., Pelletier, G., and Vaudry, H. (1994). Immunocytochemical localization and biological activity of 3 beta-hydroxysteroid dehydrogenase in the central nervous system of the frog. J. Neurosci. 14, 7306-7318.

Mensah-Nyagan, A. G., Meyer, L., Schaeffer, V., Kibaly, C., and PatteMensah, C. (2009). Evidence for a key role of steroids in the modulation of pain. Psychoneuroendocrinology 34(Suppl. 1), S169-S177.

Meyer zu Horste, G., Prukop, T., Liebetanz, D., Mobius, W., Nave, K. A., and Sereda, M. W. (2007). Antiprogesterone therapy uncouples axonal loss from demyelination in a transgenic rat model of CMT1A neuropathy. Ann. Neurol. 61, 61-72.

Mi, S., Miller, R. H., Tang, W., Lee, X., Hu, B., Wu, W., Zhang, Y., Shields, C. B., Zhang, Y., Miklasz, S., Shea, D. Mason, J., Franklin, R. J., Ji, B., Shao, Z., Chedotal, A., Bernard, F., Roulois A., Xu, J., Jung, V., and Pepinsky, B. (2009). Promotion of central nervous system remyelination by induced differentiation of oligodendrocyte precursor cells. Ann. Neurol. 65, 304-315.

Michailov, G. V., Sereda, M. W., Brinkmann, B. G., Fischer, T. M., Haug, B., Birchmeier, C., Role, L., Lai, C., Schwab, M. H., and Nave, K. A. (2004). Axonal neuregulin-1 regulates myelin sheath thickness. Science 304, 700-703.

Miron, V. E., Ludwin, S. K., Darlington, P. J., Jarjour, A. A., Soliven, B., Kennedy, T. E., and Antel, J. P. (2010). Fingolimod (FTY720) enhances remyelination following demyelination of organotypic cerebellar slices. Am. J. Pathol. 176, 2682-2694.

Mirsky, R., Woodhoo, A., Parkinson, D. B., Arthur-Farraj, P., Bhaskaran, A., and Jessen, K. R. (2008). Novel signals controlling embryonic Schwann cell development, myelination and dedifferentiation. J. Peripher. Nerv. Syst. 13, 122-135.

Morell, P., and Jurevics, H. (1996). Origin of cholesterol in myelin. Neurochem. Res. 21, 463-470.

Nave, K. A., and Trapp, B. D. (2008). Axon-glial signaling and the glial support of axon function. Annu. Rev. Neurosci. 31, 535-561.

Nguyen, P. N., Billiards, S. S., Walker, D. W., and Hirst, J. J. (2003). Changes in 5alpha-pregnane steroids and neurosteroidogenic enzyme expression in fetal sheep with umbilicoplacental embolization. Pediatr. Res. 54, 840-847.

Nguyen, P. N., Yan, E. B., CastilloMelendez, M., Walker, D. W., and Hirst, J. J. (2004). Increased allopregnanolone levels in the fetal sheep brain following umbilical cord occlusion. J. Physiol. (Lond.) 560, 593-602.

Nishiyama, A. (2001). NG2 cells in the brain: a novel glial cell population. Hum. Cell 14, 77-82. 
Noonan, C. W., Kathman, S. J., and White, M. C. (2002). Prevalence estimates for MS in the United States and evidence of an increasing trend for women. Neurology 58, 136-138.

Noorbakhsh, F., Ellestad, K. K., Maingat, F., Warren, K. G., Han, M. H., Steinman, L., Baker, G. B., and Power, C. (2011). Impaired neurosteroid synthesis in multiple sclerosis. Brain 134, 2703-2721.

Notterpek, L. M., Bullock, P. N., Malek, H., Fisher, R., and Rome, L. H. (1993). Myelination in cerebellar slice cultures: development of a system amenable to biochemical analysis. J. Neurosci. Res. 36, 621-634.

Offner, H. (2004). Neuroimmunoprotective effects of estrogen and derivatives in experimental autoimmune encephalomyelitis: therapeutic implications for multiple sclerosis. J. Neurosci. Res. 78, 603-624.

Okret, S., Dong, Y., Tanaka, H., Cairns, B., and Gustafsson, J. A. (1991). The mechanism for glucocorticoidresistance in a rat hepatoma cell variant that contains functional glucocorticoid receptor. J. Steroid Biochem. Mol. Biol. 40, 353-361.

O'Leary, M. T., Hinks, G. L., Charlton, H. M., and Franklin, R. J. (2002). Increasing local levels of IGF-I mRNA expression using adenoviral vectors does not alter oligodendrocyte remyelination in the CNS of aged rats. Mol. Cell. Neurosci. $19,32-42$.

Papadopoulos, V., Baraldi, M., Guilarte, T. R., Knudsen, T. B., Lacapere, J. J., Lindemann, P., Norenberg, M. D., Nutt, D., Weizman, A., Zhang, M. R., and Gavish, M. (2006). Translocator protein $(18 \mathrm{kDa})$ : new nomenclature for the peripheraltype benzodiazepine receptor based on its structure and molecular function. Trends Pharmacol. Sci. 27, 402-409.

Papadopoulos, V., and Lecanu, L. (2009). Translocator protein (18 kDa) TSPO: an emerging therapeutic target in neurotrauma. Exp. Neurol. 217, 53-57.

Pardridge, W. M., and Mietus, L. J. (1979). Transport of steroid hormones through the rat blood-brain barrier. Primary role of albuminbound hormone. J. Clin. Invest. 64, 145-154.

Parsons, B., MacLusky, N. J., Krey, L., Pfaff, D. W., and McEwen, B. S. (1980). The temporal relationship between estrogen-inducible progestin receptors in the female rat brain and the time course of estrogen activation of mating behavior. Endocrinology 107, 774-779.

Patte-Mensah, C., Kappes, V., FreundMercier, M. J., Tsutsui, K., and Mensah-Nyagan, A. G. (2003). Cellular distribution and bioactivity of the key steroidogenic enzyme, cytochrome P450side chain cleavage, in sensory neural pathways. $J$. Neurochem. 86, 1233-1246.

Patte-Mensah, C., Li, S., and MensahNyagan, A. G. (2004a). Impact of neuropathic pain on the gene expression and activity of cytochrome P450side-chain-cleavage in sensory neural networks. Cell. Mol. Life Sci. 61, 2274-2284.

Patte-Mensah, C., Penning, T. M., and Mensah-Nyagan, A. G. (2004b). Anatomical and cellular localization of neuroactive 5 alpha/3 alpha-reduced steroid-synthesizing enzymes in the spinal cord. J. Comp. Neurol. 477, 286-299.

Patte-Mensah, C., Meyer, L., Schaeffer, V., and Mensah-Nyagan, A. G. (2010). Selective regulation of 3 alpha-hydroxysteroid oxidoreductase expression in dorsal root ganglion neurons: a possible mechanism to cope with peripheral nerve injury-induced chronic pain. Pain 150, 522-534.

Pelletier, G. (2010). Steroidogenic enzymes in the brain: morphological aspects. Prog. Brain Res. 181, 193-207.

Penning, T. M. (2011). Human hydroxysteroid dehydrogenases and prereceptor regulation: insights into inhibitor design and evaluation. J. Steroid Biochem. Mol. Biol. 125, 46-56.

Penning, T. M., Jin, Y., Heredia, V. V., and Lewis, M. (2003). Structurefunction relationships in 3alphahydroxysteroid dehydrogenases: a comparison of the rat and human isoforms. J. Steroid Biochem. Mol. Biol. 85, 247-255.

Penning, T. M., Jin, Y., Steckelbroeck, S., Lanisnik, R. T., and Lewis, M. (2004). Structure-function of human 3 alpha-hydroxysteroid dehydrogenases: genes and proteins. Mol. Cell. Endocrinol. 215, 63-72.

Pfaff, D. W., and McEwen, B. S. (1983). Actions of estrogens and progestins on nerve cells. Science 219, 808-814.

Poisbeau, P., Patte-Mensah, C., Keller, A. F., Barrot, M., Breton, J. D., LuisDelgado, O. E., Freund-Mercier, M. J., Mensah-Nyagan, A. G., and Schlichter, R. (2005). Inflammatory pain upregulates spinal inhibition via endogenous neurosteroid production. J. Neurosci. 25, 11768-11776.
Puia, G., Mienville, J. M., Matsumoto, K., Takahata, H., Watanabe, H., Costa, E., and Guidotti, A. (2003). On the putative physiological role of allopregnanolone on $\operatorname{GABA}(\mathrm{A})$ receptor function. Neuropharmacol ogy 44, 49-55.

Quarles, R. H., Macklin, W. B., and Morell, P. (2006). "Myelin formation, structure and biochemistry," in Basic Neurochemistry: Molecular Cellular and Medical Aspects, eds G. J. Siegel, W. R. Albers, S. T. Brady, and D. L. Price (London: Elsevier) 51-71.

Resko, J. A. (1969). Endocrine control of adrenal progesterone secretion in the ovariectomized rat. Science 164, 70-71.

Robert, F., Guennoun, R., Désarnaud, F., Do-Thi, A., Benmessahel, Y., Baulieu, E. E., and Schumacher, M. (2001). Synthesis of progesterone in Schwann cells: regulation by sensory neurons. Eur. J. Neurosci. 13, 916-924.

Romeo, E., Cavallaro, S., Korneyev, A. Kozikowski, A. P., Ma, D., Polo, A., Costa, E., and Guidotti, A. (1993). Stimulation of brain steroidogenesis by 2 -aryl-indole-3-acetamide derivatives acting at the mitochondrial diazepam-binding inhibitor receptor complex. J. Pharmacol. Exp. Ther. 267, 462-471.

Rupprecht, R., Papadopoulos, V., Rammes, G., Baghai, T. C., Fan, J., Akula, N., Groyer, G., Adams, D., and Schumacher, M. (2010). Translocator protein $(18 \mathrm{kDa})$ (TSPO) as a therapeutic target for neurological and psychiatric disorders. Nat. Rev. Drug Discov. 9, 971-988.

Rupprecht, R., Rammes, G., Eser, D. Baghai, T. C., Schule, C., Nothdurfter, C., Troxler, T., Gentsch, C., Kalkman, H. O., Chaperon, F., Uzunov, V., McAllister, K. H., Bertaina-Anglade, V., La Rochelle, C. D., Tuerck, D., Floesser, A., Kiese, B., Schumacher, M. Landgraf, R., Holsboer, F., and Kucher, K. (2009). Translocator protein $(18 \mathrm{kD})$ as target for anxiolytics without benzodiazepinelike side effects. Science 325, 490-493.

Saalmann, Y. B., Morgan, I. G., and Calford, M. B. (2006). Neurosteroids involved in regulating inhibition in the inferior colliculus. J. Neurophysiol. 96, 3064-3073.

Saher, G., Brugger, B., Lappe-Siefke, C., Mobius, W., Tozawa, R., Wehr, M. C., Wieland, F., Ishibashi, S., and Nave, K. A. (2005). High cholesterol level is essential for myelin membrane growth. Nat. Neurosci. 8 , 468-475.

Saher, G., Quintes, S., Mobius, W., Wehr, M. C., Kramer-Albers, E. M., Brugger, B., and Nave, K. A. (2009). Cholesterol regulates the endoplasmic reticulum exit of the major membrane protein $\mathrm{P} 0$ required for peripheral myelin compaction. J. Neurosci. 29, 6094-6104.

Sakamoto, H., Ukena, K., and Tsutsui, K. (2001). Effects of progesterone synthesized de novo in the developing Purkinje cell on its dendritic growth and synaptogenesis. J. Neurosci. 21, 6221-6232.

Saredi, S., Patte-Mensah, C., Melcangi, R. C., and Mensah-Nyagan, A. G. (2005). Effect of streptozotocininduced diabetes on the gene expression and biological activity of 3betahydroxysteroid dehydrogenase in the rat spinal cord. Neuroscience 135 , 869-877.

Sayeed, I., Guo, Q., Hoffman, S. W., and Stein, D. G. (2006) Allopregnanolone, a progesterone metabolite, is more effective than progesterone in reducing cortical infarct volume after transient middle cerebral artery occlusion. Ann. Emerg. Med. 47, 381-389.

Schaeffer, V., Meyer, L., Patte-Mensah, C., Eckert, A., and Mensah-Nyagan, A. G. (2008). Dose-dependent and sequence-sensitive effects of amyloid-beta peptide on neurosteroidogenesis in human neuroblastoma cells. Neurochem. Int. 52, 948-955.

Schumacher, M., Guennoun, R. Ghoumari, A., Massaad, C., Robert, F., El-Etr, M., Akwa, Y., Rajkowski, K., and Baulieu, E. E. (2007). Novel perspectives for progesterone in hormone replacement therapy, with special reference to the nervous system. Endocr. Rev. 28, 387-439.

Schumacher, M., Sitruk-Ware, R., and De Nicola, A. F. (2008). Progesterone and progestins: neuroprotection and myelin repair. Curr. Opin. Pharmacol. 8, 740-746.

Schumacher, M., Weill-Engerer, S., Liere, P., Robert, F., Franklin, R. J., Garcia-Segura, L. M., Lambert, J. J., Mayo, W., Melcangi, R. C., Parducz, A., Suter, U., Carelli, C., Baulieu, E. E., and Akwa, Y. (2003). Steroid hormones and neurosteroids in normal and pathological aging of the nervous system. Prog. Neurobiol. 71, 3-29.

Sereda, M. W., Meyer, Z., Suter, U., Uzma, N., and Nave, K. A. (2003). Therapeutic administration of progesterone antagonist in a 
model of Charcot-Marie-Tooth disease (CMT-1A). Nat. Med. 9, 1533-1537.

Serra, M., Madau, P., Chessa, M. F., Caddeo, M., Sanna, E., Trapani, G., Franco, M., Liso, G., Purdy, R. H., Barbaccia, M. L., and Biggio, G. (1999). 2-Phenyl-imidazo[1,2a]pyridine derivatives as ligands for peripheral benzodiazepine receptors: stimulation of neurosteroid synthesis and anticonflict action in rats. Br. J. Pharmacol. 127, 177-187.

Shy, M. E. (2006). Peripheral neuropathies caused by mutations in the myelin protein zero. J. Neurol. Sci. 242, 55-66.

Siegenthaler, M. M., Tu, M. K., and Keirstead, H. S. (2007). The extent of myelin pathology differs following contusion and transection spinal cord injury. J. Neurotrauma 24, 1631-1646.

Sim, F. J., Zhao, C., Li, W. W., Lakatos, A., and Franklin, R. J. (2002). Expression of the POU-domain transcription factors SCIP/Oct-6 and Brn-2 is associated with Schwann cell but not oligodendrocyte remyelination of the CNS. Mol. Cell. Neurosci. 20, 669-682.

Simard, J., Ricketts, M. L., Gingras, S., Soucy, P., Feltus, F. A., and Melner, M. H. (2005). Molecular biology of the 3beta-hydroxysteroid dehydrogenase/delta5-delta4 isomerase gene family. Endocr. Rev. 26, 525-582.

Simons, M., and Trajkovic, K. (2006). Neuron-glia communication in the control of oligodendrocyte function and myelin biogenesis. J. Cell. Sci. 119, 4381-4389.

Sitruk-Ware, R., Small, M., Kumar, N., Tsong, Y. Y., Sundaram, K., and Jackanicz, T. (2003). Nestorone: clinical applications for contraception and HRT. Steroids 68, 907-913.

Soma, K. K., Sinchak, K., Lakhter, A., Schlinger, B. A., and Micevych, P. E. (2005). Neurosteroids and female reproduction: estrogen increases 3beta-HSD mRNA and activity in rat hypothalamus. Endocrinology 146, 4386-4390.

Spence, R. D., Hamby, M. E., Umeda, E., Itoh, N., Du, S., Wisdom, A. J., Cao, Y., Bondar, G., Lam, J., Ao, Y., Sandoval, F., Suriany, S., Sofroniew, M. V., and Voskuhl, R. R. (2011). Neuroprotection mediated through estrogen receptor-alpha in astrocytes. Proc. Natl. Acad. Sci. U.S.A. 108, 8867-8872.

Stanczyk, F. Z. (2003). All progestins are not created equal. Steroids 68, 879-890.
Stanczyk, F. Z., and Henzl, M. R. (2001). Use of the name "Progestin". Contraception 64, 1-2.

Steckelbroeck, S., Watzka, M., Reichelt, R., Hans, V. H., Stoffel, W., Heidrich, D. D., Schramm, J., Bidlingmaier, F., and Klingmuller, D. (2001). Characterization of the 5alpha-reductase3alpha-hydroxysteroid dehydrogenase complex in the human brain. J. Clin. Endocrinol. Metab. 86, 1324-1331.

Stein, D. G. (2001). Brain damage, sex hormones and recovery: a new role for progesterone and estrogen? Trends Neurosci. 24, 386-391.

Stein, D. G., and Wright, D. W. (2010). Progesterone in the clinical treatment of acute traumatic brain injury. Expert Opin. Investig. Drugs $19,847-857$.

Stoffel, W., Watzka, M., Steckelbroeck, S., Ludwig, M., Clusmann, H., Bidlingmaier, F., Casarosa, E., Luisi, S., Elger, C. E., and Beyenburg, S. (2003). Allopregnanolone serum levels and expression of 5 alpha-reductase and 3 alphahydroxysteroid dehydrogenase isoforms in hippocampal and temporal cortex of patients with epilepsy. Epilepsy Res. 54, 11-19.

Stoffel-Wagner, B. (2001). Neurosteroid metabolism in the human brain. Eur. J. Endocrinol. 145, 669-679.

Stuve, O., Kieseier, B. C., Hemmer, B., Hartung, H. P., Awad, A., Frohman, E. M., Greenberg, B. M., Racke, M. K., Zamvil, S. S., Phillips, J. T., Gold, R., Chan, A., Zettl, U., Milo, R., Marder, E., Khan, O., and Eagar, T. N. (2010). Translational research in neurology and neuroscience 2010: multiple sclerosis. Arch. Neurol. 67, 1307-1315.

Suter, U., and Scherer, S. S. (2003). Disease mechanisms in inherited neuropathies. Nat. Rev. Neurosci. 4, 714-726.

Suter, U., Snipes, J. G., Schoener-Scott, R., Welcher, A. A., Pareek, S., Lupski, J. R., Murphy, R. A., Shooter, E. M., and Patel, P. I. (1994). Regulation of tissue-specific expression of alternative peripheral myelin protein22 (PMP22) gene transcripts by two promoters. J. Biol. Chem. 269, 25795-25808.

Szekeres-Bartho, J., Halasz, M., and Palkovics, T. (2009). Progesterone in pregnancy; receptor-ligand interaction and signaling pathways. $J$. Reprod. Immunol. 83, 60-64.

Talbott, J. F., Loy, D. N., Liu, Y., Qiu, M. S., Bunge, M. B., Rao, M. S., and Whittemore, S. R. (2005). Endogenous Nkx2.2+/Olig2+ oligodendrocyte precursor cells fail to remyelinate the demyelinated adult rat spinal cord in the absence of astrocytes. Exp. Neurol. 192, 11-24.

Thi, A. D., Jung-Testas, I., and Baulieu, E. E. (1998). Neuronal signals are required for estrogen-mediated induction of progesterone receptor in cultured rat Schwann cells. J. Steroid Biochem. Mol. Biol. 67, 201-211.

Thomas, P., Pang, Y., Dong, J., Groenen, P., Kelder, J., de Vlieg, J. Zhu, Y., and Tubbs, C. (2007). Steroid and $\mathrm{G}$ protein binding characteristics of the seatrout and human progestin membrane receptor alpha subtypes and their evolutionary origins. Endocrinology 148 705-718.

Trapp, B. D., and Nave, K. A. (2008) Multiple sclerosis: an immune or neurodegenerative disorder? Апnи. Rev. Neurosci. 31, 247-269.

Tsutsui, K., Sakamoto, H., Shikimi, H., and Ukena, K. (2004). Organizing actions of neurosteroids in the Purkinje neuron. Neurosci. Res. 49, 273-279.

Tuckey, R. C. (2005). Progesterone synthesis by the human placenta. Placenta 26, 273-281.

Ukena, K., Kohchi, C., and Tsutsui, K. (1999). Expression and activity of 3beta-hydroxysteroid dehydrogenase/delta5-delta4isomerase in the rat Purkinje neuron during neonatal life. Endocrinology 140, 805-813.

Ukena, K., Usui, M., Kohchi, C. and Tsutsui, K. (1998). Cytochrome P450 side-chain cleavage enzyme in the cerebellar Purkinje neuron and its neonatal change in rats. Endocrinology 139, 137-147.

Uzunova, V., Sampson, L., and Uzunov, D. P. (2006). Relevance of endogenous 3alpha-reduced neurosteroids to depression and antidepressant action. Psychopharmacology (Berl.) 186, 351-361

Verleye, M., Akwa, Y., Liere, P., Ladurelle, N., Pianos, A., Eychenne, B., Schumacher, M., and Gillardin, J. M. (2005). The anxiolytic etifoxine activates the peripheral benzodiazepine receptor and increases the neurosteroid levels in rat brain. Pharmacol. Biochem. Behav. 82, 712-720.

Vukusic, S., Ionescu, I., El-Etr, M., Schumacher, M., Baulieu, E. E., Cornu, C., and Confavreux, C. (2009). The prevention of post-partum relapses with progestin and estradiol in multiple sclerosis (POPART'MUS) trial: rationale, objectives and state of advancement. J. Neurol. Sci. 286, 114-118.
Wang, C., and Swerdloff, R. S. (2010). Hormonal approaches to male contraception. Curr. Opin. Urol. 20, 520-524.

Wang, J. M., Liu, L., Irwin, R. W., Chen, S., and Brinton, R. D. (2008). Regenerative potential of allopregnanolone. Brain Res. Rev. 57, 398-409.

Waters, E. M., Torres-Reveron, A., McEwen, B. S., and Milner, T. A. (2008). Ultrastructural localization of extranuclear progestin receptors in the rat hippocampal formation. J. Comp. Neurol. 511, 34-46.

Watzka, M., Bidlingmaier, F., Schramm, J., Klingmuller, D., and StoffelWagner, B. (1999). Sex-and agespecific differences in human brain CYP11A1 mRNA expression. J. Neuroendocrinol. 11, 901-905.

Weill-Engerer, S., David, J. P., Sazdovitch, V., Liere, P., Eychenne, B., Pianos, A., Schumacher, M., Delacourte, A., Baulieu, E. E., and Akwa, Y. (2002). Neurosteroid quantification in human brain regions: comparison between Alzheimer's and non-demented patients. J. Clin. Endocrinol. Metab. 87, 5138-5143.

Wise, P. M. (2002). Estrogens and neuroprotection. Trends Endocrinol. Metab. 13, 229-230.

Wright, D. W., Kellermann, A. L., Hertzberg, V. S., Clark, P. L., Frankel, M., Goldstein, F. C., Salomone, J. P., Dent, L. L., Harris, O. A., Ander, D. S., Lowery, D. W., Patel, M. M., Denson, D. D., Gordon, A. B., Wald, M. M., Gupta, S., Hoffman, S. W., and Stein, D. G. (2007). ProTECT: a randomized clinical trial of progesterone for acute traumatic brain injury. Ann. Emerg. Med. 49, 391-402.

Xiao, G., Wei, J., Yan, W., Wang, W., and $\mathrm{Lu}, \mathrm{Z}$. (2008). Improved outcomes from the administration of progesterone for patients with acute severe traumatic brain injury: a randomized controlled trial. Crit. Care 12, R61.

Yates, M. A., Li, Y., Chlebeck, P., Proctor, T., Vandenbark, A. A., and Offner, H. (2010). Progesterone treatment reduces disease severity and increases IL-10 in experimental autoimmune encephalomyelitis. J. Neuroimmunol. 220, 136-139.

Yawno, T., Yan, E. B., Walker, D. W., and Hirst, J. J. (2007). Inhibition of neurosteroid synthesis increases asphyxia-induced brain injury in the late gestation fetal sheep. Neuroscience 146, 1726-1733.

Yin, X., Baek, R. C., Kirschner, D. A., Peterson, A., Fujii, Y., Nave, K. A., 
Macklin, W. B., and Trapp, B. D. (2006). Evolution of a neuroprotective function of central nervous system myelin. J. Cell Biol. 172, 469-478.

Yu, H. J., Fei, J., Chen, X. S., Cai, Q. Y., Liu, H. L., Liu, G. D., and Yao, Z. X. (2010). Progesterone attenuates neurological behavioral deficits of experimental autoimmune encephalomyelitis through remyelination with nucleus-sublocalized Olig1 protein. Neurosci. Lett. 476, 42-45.
Yu, L., Romero, D. G., Gomez-Sanchez, C. E., and Gomez-Sanchez, E. P. (2002). Steroidogenic enzyme gene expression in the human brain. Mol. Cell. Endocrinol. 190, 9-17.

Zwain, I. H., and Yen, S. S. (1999). Neurosteroidogenesis in astrocytes, oligodendrocytes, and neurons of cerebral cortex of rat brain. Endocrinology 140, 3843-3852.

Conflict of Interest Statement: The authors declare that the research was conducted in the absence of any commercial or financial relationships that could be construed as a potential conflict of interest.

Received: 11 November 2011; paper pending published: 05 December 2011; accepted: 16 January 2012; published online: 08 February 2012.

Citation: Schumacher $M$, Hussain R, Gago N, Oudinet J-P, Mattern C and Ghoumari AM (2012) Progesterone synthesis in the nervous system: implications for myelination and myelin repair. Front. Neurosci. 6:10. doi: 10.3389/fnins.2012.00010

This article was submitted to Frontiers in Neuroendocrine Science, a specialty of Frontiers in Neuroscience.

Copyright () 2012 Schumacher, Hussain, Gago, Oudinet, Mattern and Ghoumari. This is an open-access article distributed under the terms of the Creative Commons Attribution Non Commercial License, which permits non-commercial use, distribution, and reproduction in other forums, provided the original authors and source are credited. 